\title{
Does Wage Dispersion Make All Firms Productive?
}

\section{Benoît Mahy, François Rycx and Mélanie Volral}

This article puts the relationship between wage dispersion and firm productivity to an updated test, taking advantage of access to detailed Belgian linked employer-employee panel data. Controlling for simultaneity issues, timeinvariant workplace characteristics and dynamics in the adjustment process of productivity, empirical results reveal the existence of a positive impact from conditional intra-firm wage dispersion to firm productivity (measured by the average value added per hour worked), which however decreases for higher dispersion levels. Findings thus suggest that the incentive effect of wage dispersion, predicted for instance by the 'tournament' model, dominates 'fairness' and/or 'sabotage' considerations. Further results reveal that the influence of wage dispersion on firm productivity is stronger among firms with a larger proportion of highly skilled workers but does not depend on whether wages are collectively renegotiated at the firm level.

Keywords: Wage Dispersion, Labour Productivity, Personnel Economics, Matched Employer-Employee Panel Data.

JEL Classifications: J31, J24, M5

\section{CEB Working Paper $N^{\circ} 11 / 021$ \\ 2011}




\title{
Does Wage Dispersion Make All Firms Productive?
}

\author{
Benoît MAHY \\ Université de Mons, Warocqué Research Center (CRW) and DULBEA \\ François RYCX \\ Université Libre de Bruxelles, SBS-EM (CEB and DULBEA) and IZA \\ Mélanie VOLRAL \\ Université de Mons, Warocqué Research Center (CRW)
}

\begin{abstract}
This article puts the relationship between wage dispersion and firm productivity to an updated test, taking advantage of access to detailed Belgian linked employer-employee panel data. Controlling for simultaneity issues, time-invariant workplace characteristics and dynamics in the adjustment process of productivity, empirical results reveal the existence of a positive impact from conditional intra-firm wage dispersion to firm productivity (measured by the average value added per hour worked), which however decreases for higher dispersion levels. Findings thus suggest that the incentive effect of wage dispersion, predicted for instance by the 'tournament' model, dominates 'fairness' and/or 'sabotage' considerations. Further results reveal that the influence of wage dispersion on firm productivity is stronger among firms with a larger proportion of highly skilled workers but does not depend on whether wages are collectively renegotiated at the firm level.
\end{abstract}

Keywords: Wage Dispersion, Labour Productivity, Personnel Economics, Matched Employer-Employee Panel Data.

JEL Codes: J31, J24, M5

\section{Corresponding author:}

\section{François Rycx}

Université Libre de Bruxelles

CP 114/02 - Avenue F.D. Roosevelt 50

B-1050 Brussels, Belgium

E-mail: frycx@ulb.ac.be

\footnotetext{
* We would like to thank the National Bank of Belgium for financial support and Statistics Belgium for giving access to the data. Any remaining errors are the authors' responsibility.
} 


\section{Introduction}

In the context of asymmetric information on the labour market, firms try to design appropriate incentive practices in order to optimize workers' effort. The implementation of performancerelated pay systems may contribute to the achievement of this goal. These systems can be based on absolute criteria so that individual pay depends on individual productivity (e.g. piece rates). However, they can also rely on relative indicators so that a worker's wage depends on his or her relative productivity (e.g. on the ratio of individual productivity to average productivity of all co-workers).

According to Lazear (1995), there are two reasons why firms may prefer compensation schemes based on relative rather than absolute criteria. A first argument is that the relative position of a worker may be more easily assessed than his absolute performance. Another point is that relative comparisons are not affected by common shocks to productivity (e.g. an economic downturn). On the contrary, worker's effort might be incorrectly assessed by performance-related pay systems based on absolute criteria in case of economic downturn and the associated lower output level. When shocks are important, relative performance has therefore to be privileged in order for workers involvement not to be reduced. However, relative comparisons create a negative externality of individual effort on the wages of coworkers. Indeed, if a worker increases his effort, ceteris paribus, he reduces the relative performance of his colleagues and hence their future wages. Bandiera et al. (2005) show that if workers internalize this externality, piece rates may lead to a higher average productivity than relative compensation schemes. Their empirical analysis, based on personnel data from a leading farm in the U.K., also reveals that this internalization process only occurs when workers are able to monitor each other. Whether performance pay should be based on absolute or relative criteria is thus likely to depend on the firm's working environment. Moreover, both schemes are not mutually exclusive and may be combined in order to optimise workers' productivity. For instance, Schöttner and Thiele (2007) analyse the optimal combination of promotion tournaments and linear individual performance pay in order to achieve incentive and selection goals.

The introduction of performance-related pay systems typically leads to an increase in the dispersion of wages. According to Belfield and Marsden (2003, p 456), this result is due to the fact that 'there is a greater underlying variation in the individual endowments that determine worker performance (e.g. cognitive or physical ability, risk propensity, 
determination, etc.) than in those that determine input (e.g. ability to put in eight hours per day, etc.)'. Lemieux et al. (2009) show in addition that wages are more closely tied to observed and unobserved worker characteristics in performance-related pay jobs. They also find that the growing incidence of pay-for-performance mechanisms accounts for about one quarter of the growth in the variance of male wages in the U.S. between the late 1970s and the early 1990s (and for almost all of the growth in wage dispersion observed above the 80th percentile).

The impact of a growing wage dispersion (due to the use of performance-related pay systems) on firm productivity is not clear-cut from a theoretical point of view. Lazear and Rosen (1981), for example, show that a rank-order payment scheme (i.e. a system which rewards workers on the basis of their relative position in the firm) can induce a high level of effort among workers. This scheme motivates workers by establishing an upward-sloping occupational wage profile and by awarding particularly large salaries to executives. Put differently, it incites workers to put forth effort (i.e. to perform better than their peers) in order to be promoted and increase their earnings. These ideas, at the basis of Lazear and Rosen's (1981) 'tournament' model, thus suggest that a differentiated wage structure is good for firm productivity. However, other theories based on 'fairness' considerations stress that wage compression stimulates cohesiveness among the workforce and is therefore beneficial for productivity (Akerlof and Yellen, 1988; Levine, 1991; Milgrom and Roberts, 1990).

The empirical evidence regarding the impact of wage inequality on firm productivity is also very inconclusive (e.g. Eriksson, 1999; Hibbs and Locking, 2000; Lallemand et al., 2007; Martins, 2008; Winter-Ebmer and Zweimüller, 1999). Moreover, findings must be interpreted with caution because of methodological and/or data limitations (i.e. in terms of indicators used, data coverage or estimation strategy). In addition, only few studies consider that this relationship might be influenced by specific working environments, even though, as indicated by Pfeffer and Langton (1993, p 383), 'one of the more useful avenues for research on pay systems may be precisely this task of determining not which pay scheme is best but, rather, under what conditions salary dispersion has positive effects and under what conditions it has negative effects'.

Therefore, the aim of this paper is twofold. First, it puts the relationship between wage dispersion and firm productivity to an updated test, taking advantage of access to detailed Belgian linked employer-employee (hereafter LEE) panel data for the years 1999-2006. These data offer several advantages. On the one hand, the panel covers a large part of the private sector, provides accurate information on average productivity (i.e. on the average value added 
per hour worked) and allows to control for a wide range of worker and firm characteristics (such as education, occupation, gender, working time, firm size and sector). On the other hand, it enables to compute an indicator for conditional intra-firm wage dispersion (i.e. a measure of the variation in earnings that controls for observed worker characteristics) and to address important methodological issues such as firm-level time-invariant heterogeneity, endogeneity of wage dispersion and state dependence of firm productivity. Second, the paper investigates whether the impact of wage inequality on firm productivity varies across working environments. More precisely, it examines the interaction with the skills of the workforce and the industrial relations regime. To our knowledge, the second issue has so far only been empirically explored by Jirjahn and Kraft (2007) with German data.

The remainder of this paper is organised as follows. Section 2 reviews the literature regarding the impact of wage dispersion on firm productivity. We describe our methodology in Section 3 and present the data set in Section 4. The impact of intra-firm wage dispersion on firm productivity is analysed in Section 5. Section 6 concludes.

\section{Review of the literature}

\subsection{Wage dispersion and firm productivity}

The theoretical literature disagrees on how intra-firm wage dispersion may affect productivity. On the one hand, theories based on 'fairness' considerations emphasize that wage compression improves labour relations, stimulates the cohesiveness among workers (Akerlof and Yellen, 1988; Levine, 1991) and reduces personal rent-seeking activities (Milgrom and Roberts, 1990), which in turn is beneficial for firm performance. On the other hand, the 'tournament' model (Lazear and Rosen, 1981) points out that a more differentiated wage structure stimulates workers' effort through the incentive resulting from awarding the largest prize to the most productive worker. ${ }^{1}$ However, Lazear (1989) later shows in his 'industrial politics and sabotage' model that tournament theory might also sometimes imply wage compression. The point is that if workers compete for the same prize, their effort might be misdirected away from competition to sabotage or unfair attempts to induce rivals' failure

\footnotetext{
${ }^{1}$ As highlighted in the introduction, a dispersed wage structure can also arise from other types of pay-forperformance mechanisms. The association between wage inequality and performance-related pay schemes based on absolute criteria is for instance documented in Heywood and Jirjahn (2006).
} 
in order to win the prize. Lazear (1989) therefore points out that a compressed wage structure should be preferred when the initial incentive effect of a performance-related pay system is offset by a lower degree of work cohesion due to the sabotage behaviour of some workers.

Empirical studies investigating the impact of wage dispersion on firm performance also provide very different conclusions (see Appendix 1). Moreover, results must often be considered with care due to methodological and/or data limitations. Initial papers regarding the effects of wage dispersion on firm productivity were generally restricted to a particular segment of the labour force (e.g. the top-management level) or a specific sector of the economy (e.g. professional team sports). More recently, the availability for certain countries of LEE data, covering large parts of the economy and including firm-level information on financial variables, has allowed to extend the analysis to broader occupational groups and industries. However, the validity of most studies is hampered by various shortcomings. A number of papers rely on unconditional indicators of wage dispersion, while 'tournament' and 'fairness' theories assume workers with comparable characteristics and therefore suggest the use of conditional indicators. Moreover, whereas theoretical predictions refer to productivity effects of wage inequality, studies often consider (due to data limitations) proxies like the value of production, sales or profits. The potential simultaneity between productivity and wage dispersion is another problem that is generally not addressed. Yet, it may be argued that highly productive firms pay larger wages to their most productive workers, which in turn leads to more wage dispersion. Many studies are also limited by the use of cross-sectional data, so that the causality from wage dispersion to productivity cannot be tested. In addition, the potential state dependence of firm productivity is rarely controlled for, even though current firm productivity is likely to depend on past values. Finally, Bond (2002, p 156) argues that adopting a dynamic specification is sometimes useful 'for identifying the parameters of interest, even when the dynamics themselves are not the principal focus of attention'.

To our knowledge, only eight papers investigate the relationship between wage dispersion and firm performance for broad occupational groups and industries (i.e. not exclusively for executives or sports professionals) while controlling for firm time-invariant heterogeneity (see Table 1).

[Insert Table 1] 
Yet, only half of these papers rely on a conditional indicator of wage dispersion and address the simultaneity problem. Moreover, Braakmann (2008) provides the only study controlling for potential state dependence of productivity in addition to the issues mentioned above. It is also worth to mention that a minority of these papers actually examine the productivity effects of wage inequality by using more appropriate measures suggested by theory. More precisely, they use as dependent variable the firm value added divided by the number of employees. This indicator, however, remains somewhat crude as it does not control for the mean number of working hours within firms (and for changes in this variable over time). It thus mechanically underestimates the productivity in firms employing a larger (or growing) proportion of part-time workers and may lead to biased estimates. Information on firm-level value added per hour worked or full-time equivalent worker would obviously enable to overcome this problem.

\subsection{Working environments}

Articles investigating the impact of wage dispersion on firm productivity across working environments are not numerous. However, studies like Pfeffer and Langton (1993) suggest that the magnitude of the negative impact of wage dispersion on academic departments' performance depends on a person's position in the salary structure and factors such as information, commitment, consensus and the level of certainty in the evaluation process. Beaumont and Harris (2003) show that the impact of pay inequality on U.K. firm performance depends on the sector and on differences in firm size and ownership. Koubi and Roux (2006) analyse the influence of wage dispersion on firm performance across different sectors in France. According to their estimates, the elasticity between productivity and wage dispersion is strongest in the construction industry and appears to be insignificant in services. Using data from the U.K., Belfield and Marsden (2003) find that the extent to which the use of performance-related pay increases performance depends on the structure of monitoring environments.

Overall, existing studies clearly indicate that the impact of wage dispersion on firm productivity depends substantially on the working environment. In this paper, we investigate the role played by i) the skills of the workforce and ii) the industrial relations regime.

There is no consensus on how workers' skills may affect the relationship between wage dispersion and firm productivity. According to Lazear (1989, 1995), Milgrom (1988) and Milgrom and Roberts (1990), a more compressed wage structure should theoretically be more 
optimal for highly skilled workers when they behave more opportunistically (e.g. are more willing to engage in sabotage or rent-seeking activities in case of excessive wage dispersion). In contrast, Prendergast (2002) suggests that it is more important to tie wages to firm performance for highly skilled workers as they are more likely to occupy complex jobs that are harder to monitor. This point of view is also supported by Foss and Laursen (2005) who argue that performance pay is less required in 'low-knowledge' industries (mainly employing low-skilled workers) as the latter are less confronted with problems caused by asymmetrical information. Another reason, suggested by Barth et al. (2008), for why high-skilled workers should be more intensively paid according to performance than their low-skilled counterparts, is that the former might increase their productivity more easily than the latter. Empirical studies regarding the effect of workers' skills on the elasticity between performance and wage dispersion also provide mixed results (Bingley and Eriksson, 2001; Grund and WestergaardNielsen, 2008; Lallemand et al, 2007; Winter-Ebmer and Zweimüller, 1999). Moreover, they might be limited by the fact that they rely on the distinction between white- and blue-collar staff to measure the level of skills. Indeed, this choice might not be the most appropriate as some blue-collar workers occupy jobs requiring more skills than those brought to bear by white-collar workers. Mahy et al. (2010) aim to avoid this problem using information on the workers' education and occupation and by assuming that highly skilled workers have a higher level of education than their low-skilled counterparts and occupy jobs requiring more skills. Using cross-sectional data for Belgium, they find that the intensity of the relationship between wage dispersion and firm productivity is stronger for highly skilled workers.

Another important issue is whether the elasticity between productivity and wage dispersion depends on the industrial relations regime. It is often argued that unions tend to reduce the use of pay-for-performance mechanisms (and wage dispersion) because of i) the increased risk of favoritism and discrimination and ii) the greater solidarity between workers and power of unions when workers receive similar wages (Brown, 1990; Freeman, 1982; Lemieux et al., 2009). According to Barth et al. (2008), unions could also decrease the need for performance-related pay as they bargain over rent-sharing, which could already motivate workers. However, the fact that unions are generally averse to wage dispersion and performance pay does not imply that the impact of wage dispersion on firm performance will be weaker in the presence of strong unions. According to Pfeffer and Langton (1993), the effect of performance pay (i.e. increased wage dispersion) on firm performance depends positively on factors such as information, commitment, consensus and certainty in the evaluation process. One could expect those factors to be more present in firms where 
performance pay systems are implemented with the agreement of trade unions. Bryson et al. (2005, p 453) also highlight unions' ability to act as a voice for workers, 'helping them to overcome the incentive problems in generating public goods such as better health and safety conditions in the workplace'. Unions could thereby strengthen incentives provided by wage dispersion and therefore favour firms' productivity. If this is indeed the case, then wage dispersion would be more productivity-enhancing in firms with strong union representation. However, Bryson et al. (2005) stress the importance of the interaction between unions and the management. Moreover, the extent to which relations are based on trust further conditions how productivity relates to incentives. It can also be argued that collective bargaining may create difficulties for firms to pursue a coherent internal wage policy with effective differential rewards (Jirjahn and Kraft, 2007). This would then imply that pay-forperformance mechanisms are less efficient in firms with strong unions.

To our knowledge, Jirjahn and Kraft (2007) is the only empirical study investigating whether the relationship between wage dispersion and productivity depends on (different facets of) the industrial relations regime. Using cross-sectional data from the German manufacturing sector, they find that the elasticity between productivity and wage dispersion is weaker in the presence of a work council (i.e. a mechanism for establishment-level codetermination). The explanation for this result would be as follows. Work councils act as a collective voice that helps workers to communicate their aggregated preferences to the management, which in turn uses this information to optimize its provision of workplace public goods and to establish a more efficient personnel policy. Overall, work councils would thus lead to enhanced productivity. ${ }^{2}$ Yet, the contribution of work councils to productivity would diminish as establishment-level wage dispersion rises given that the role of work councils (i.e. the aggregation of workers' preferences and the transmission of information to the management) would become more difficult when the diversity in working conditions and/or workers rises (i.e. when wage dispersion increases). Furthermore, Jirjahn and Kraft (2007) find that the elasticity between productivity and wage dispersion is stronger in establishments that are not covered by a collective agreement. According to the authors, this finding could derive from the fact that uncovered firms are probably less constrained in their wage policy so that their wage dispersion would reflect a more balanced provision of penalties and rewards.

\footnotetext{
${ }^{2}$ This prediction is confirmed in the econometric analysis of Jirjahn and Kraft (2007).
} 
Wage bargaining in the Belgian private sector differs from that in Germany. It occurs at three levels, namely the national (or inter-professional), sectoral and company level. They generally occur every two years on a pyramidal basis. In principle, they are inaugurated by a national collective agreement defining a minimum level in wage terms. Next, this national agreement is improved within every sector of activity. Finally, sectoral collective agreements are renegotiated in some firms. However, the wage renegotiated at the firm level can only be greater than or equal to the wage set at the national and/or industry level. Given these institutional features, our empirical analysis will investigate whether the elasticity between productivity and wage dispersion is different in firms solely covered by an industry (and a previous national) agreement compared to firms in which wages are collectively renegotiated. $^{3}$

\section{Methodology}

\subsection{Basic specification}

Two types of wage dispersion indicators can be found in the literature: unconditional indicators, where wage dispersion is measured between heterogeneous workers, and conditional indicators, where wage dispersion is estimated between workers with similar characteristics. Since theories such as 'tournaments' or 'fairness' refer to wage differentials between comparable workers, we examine the impact of a conditional wage dispersion indicator on firm productivity using the two-step procedure proposed by Winter-Ebmer and Zweimüller (1999).

In the first step, we compute the conditional wage inequality indicator. Therefore, we estimate by OLS the following wage equation for each firm and each year separately:

$$
\ln \mathrm{w}_{\mathrm{ijt}}=\alpha_{0}+\mathbf{y}_{\mathrm{ijt}} \boldsymbol{\alpha}_{1}+\varepsilon_{\mathrm{ijt}}
$$

\footnotetext{
${ }^{3}$ Note that industry and firm agreements can be combined in Belgium, whereas in Germany they are mutually exclusive. Another distinctive feature is that the collective bargaining coverage rate in Belgium is above 90 percent (OECD, 2004). Only self-employed workers may not be covered by a collective wage agreement. Yet, these workers are not included in our sample.
} 
where $\mathrm{w}_{\mathrm{ijt}}$ is the gross hourly wage (including bonuses) of worker $\mathrm{i}$ in firm $\mathrm{j}$ at year $\mathrm{t}, \mathbf{y}_{\mathrm{ijt}}$ is a vector of individual characteristics including age ( 2 dummies), sex, education ( 2 dummies) and occupation ( 1 dummy), and $\varepsilon_{\mathrm{ijt}}$ is the error term. ${ }^{4}$

The standard deviations of the residuals of these regressions run firm by firm and year by year, $\sigma_{\mathrm{jt}}$, are then used as a conditional measure of wage dispersion in the second step, which consists in estimating the following firm-level productivity equation:

$$
\ln \text { va_hour }{ }_{\mathrm{jt}}=\beta_{0}+\beta_{1} \sigma_{\mathrm{jt}}+\mathbf{x}_{\mathbf{j t}} \boldsymbol{\beta}_{\mathbf{2}}+\mathbf{z}_{\mathbf{j t}} \boldsymbol{\beta}_{\mathbf{3}}+\gamma_{\mathrm{t}}+v_{\mathrm{jt}}
$$

where va_hour $\mathrm{j}_{\mathrm{jt}}$ is the productivity of firm $\mathrm{j}$ at year $\mathrm{t}$, measured by the average value added per hour worked, $\sigma_{\mathbf{j t}}$ is the conditional wage dispersion indicator, $\mathbf{x}_{\mathbf{j t}}$ is a vector containing aggregated characteristics of workers, i.e. the share of the workforce that: i) has at most a degree of lower secondary education, ii) has at least 10 years of tenure and iii) is younger than 25 and older than 49 years, respectively, the share of women and the share of blue-collar workers, $\mathbf{z}_{\mathbf{j t}}$ includes firm characteristics, i.e. sectoral affiliation ( 8 dummies), the size of the firm (number of workers) ${ }^{5}$ and the level of wage bargaining ( 1 dummy), $\gamma_{t}$ is a set of year dummies ( 7 dummies) and $v_{\mathrm{jt}}$ is the error term. ${ }^{6}$

\footnotetext{
${ }^{4}$ It could have been useful to control for additional variables such as job tasks. However, our data provide little information on the type of jobs performed by workers (apart from the International Standard Classification of Occupations). Moreover, the number of variables for which we can control is restricted due to the fact that we have only 10 observations for certain firms in a given year. This being said, descriptive statistics (reported in Table 2) show that considerable heterogeneity is already encompassed by our conditional indicator.

${ }^{5}$ We have information on whether a firm employs between 10 and 19 workers, between 20 and 49 workers, between 50 and 99 workers, between 100 and 199 workers, between 200 and 499 workers or more than 500 workers.

${ }^{6}$ Unfortunately, our data provide no direct information on firms' capital stock. However, van Ours and Stoeldraijer (2010, p10) conclude from previous studies that including or not including capital stock information doesn't seem to affect the parameter estimates of production functions based on firm-level micro survey data'. This conclusion is in line with results from the meta-analysis performed by Doucouliagos and Laroche (2003). It is also worth to mention that we have no variable on the kind of pay system used by firms. Yet, they are likely to influence the impact of wage dispersion on firm productivity. For instance, McNabb and Whitfield (2003) suggest that productivity is more enhanced when performance-related pay schemes are based on group rather than on individual measures of output. This would imply that our estimates of the relationship between wage dispersion and productivity under (over) estimate the true relation for firms using essentially performance-related pay schemes based on group (individual) measures of output.
} 
From an econometric point of view, we initially estimate equation (2) by standard OLS. Yet, a first problem to address is the potential simultaneity between firm productivity and wage dispersion. Indeed, it may be argued that highly productive firms pay larger wages to their most productive workers, which in turn leads to more wage dispersion. We address this issue by regressing the log of the value added per hour worked on the wage dispersion indicator with one year lag, $\sigma_{\mathrm{jt}-1}{ }^{7}$ This boils down to the estimation of the following equation:

$$
\text { ln va_hour }{ }_{\mathrm{jt}}=\beta_{0}+\beta_{1} \sigma_{\mathrm{jt}-1}+\mathbf{x}_{\mathbf{j t}} \boldsymbol{\beta}_{\mathbf{2}}+\mathbf{z}_{\mathbf{j t}} \boldsymbol{\beta}_{\mathbf{3}}+\gamma_{\mathrm{t}}+\tau_{\mathrm{jt}}
$$

Next, in order to control for firm fixed-effects, we reformulate equation (3) as follows:

$$
\text { ln va_hour }{ }_{\mathrm{jt}}=\beta_{0}+\beta_{1} \sigma_{\mathrm{jt}-1}+\mathbf{x}_{\mathbf{j t}} \boldsymbol{\beta}_{\mathbf{2}}+\mathbf{z}_{\mathbf{j t}} \boldsymbol{\beta}_{\mathbf{3}}+\delta_{\mathrm{j}}+\gamma_{\mathrm{t}}+\mu_{\mathrm{jt}}
$$

where $\delta_{\mathrm{j}}$ is a dummy variable for each firm which captures time-invariant workplace characteristics.

Finally, in order to control for the potential state dependence of firm productivity, we estimate equation (5) using the dynamic system GMM estimator proposed by Arellano and Bover (1995) and Blundell and Bond (1998). One year lagged productivity is thus used as an additional explanatory variable. Moreover, variables in the differenced equation are instrumented by their lagged levels and variables in the level equation are instrumented by their lagged differences. Time dummies are considered as exogeneous and we use second and third lags of other explanatory variables as instruments.

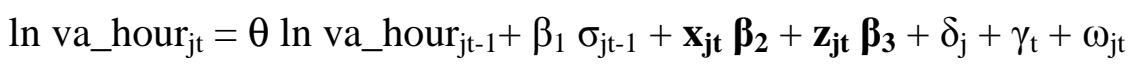

\subsection{Hump-shaped relationship}

In all equations described so far, we also test for a hump-shaped relationship between wage dispersion and firm productivity. The point is that up to (beyond) a certain level of wage dispersion, the incentive effect predicted for instance by the 'tournament' model may dominate (may be dominated by) 'fairness' and/or 'sabotage' considerations. Therefore, we

\footnotetext{
${ }^{7}$ However, this procedure should still be considered with care given that intra-firm wage inequality may be relatively persistent over time. Therefore, we also use the system GMM estimator (see equation 5).
} 
simply add the wage dispersion indicator in quadratic form to previous equations. Equation (5), for instance, then becomes:

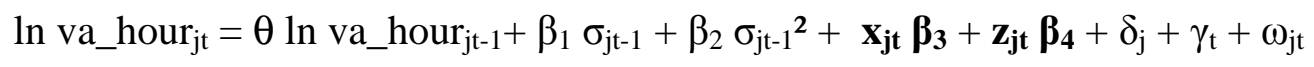

Furthermore, as there might exist a multicolinearity problem because of the correlation between the wage dispersion variables in level and squared, we also test for a concave relationship by interacting the wage dispersion indicator with two dummy variables capturing the size of intra-firm wage inequality:

$$
\begin{aligned}
\text { ln va } \_ \text {hour } & =\theta \text { ln va_hour }{ }_{j \mathrm{jt}-1}+\beta_{1} \sigma_{\mathrm{jt}-1}+\beta_{2}\left[\sigma^{*} \mathrm{D}_{1}\right]_{\mathrm{jt}-1}+\beta_{3}\left[\sigma^{*} \mathrm{D}_{2}\right]_{\mathrm{jt}-1}+\mathbf{x}_{\mathbf{j t}} \boldsymbol{\beta}_{\mathbf{4}}+\mathbf{z}_{\mathbf{j t}} \boldsymbol{\beta}_{\mathbf{5}} \\
& +\delta_{\mathrm{j}}+\gamma_{\mathrm{t}}+\omega_{\mathrm{jt}}
\end{aligned}
$$

where $D_{1}\left(D_{2}\right)$ is a dummy variable that is equal to one if intra-firm wage dispersion ranges between the $33^{\text {rd }}$ and the $66^{\text {th }}$ percentiles (is greater than or equal to the $66^{\text {th }}$ percentile) of the distribution of intra-firm wage inequality across firms.

\subsection{Interaction with working environments}

We then investigate whether the relationship between wage dispersion and firm productivity depends on working environments. We first address the skill level of the workforce. To measure it, we follow the methodology proposed by Mahy et al. (2010). This boils down to combine firm-level information on the workers' level of education and occupation and to estimate the following variant of equation (6'):

$$
\begin{aligned}
\text { ln va_hour } \mathrm{jt}=\theta \text { ln va_hour } & \\
& +\beta_{1}\left[\sigma * \sigma_{\mathrm{jt}-1}+\beta_{2}\left[\sigma * \mathrm{D}_{\mathrm{jt}-1}+\beta_{4}\left[\sigma * \mathrm{D}_{1} * \text { Low_Skilled }\right]_{\mathrm{jt}-1}\right.\right. \\
& +\beta_{5}\left[\sigma * \mathrm{D}_{2}\right]_{\mathrm{jt}-1}+\beta_{6}\left[\sigma * \mathrm{D}_{2} * \text { Low_Skilled }\right]_{\mathrm{jt}-1} \\
& +\beta_{7} \text { Low_Skilled }_{\mathrm{jt}-1}+\mathbf{x}_{\mathrm{jt}} \boldsymbol{\beta}_{\mathbf{8}}+\mathbf{z}_{\mathrm{jt}} \boldsymbol{\beta}_{\mathbf{9}}+\delta_{\mathrm{j}}+\gamma_{\mathrm{t}}+\omega_{\mathrm{jt}}
\end{aligned}
$$

where 'Low_Skilled' is a dummy variable that is equal to one if the workforce of the firm is low-skilled, i.e. if the firm presents both a proportion of low-educated workers and a 
proportion of low-ability occupations larger than their respective medians on the whole sample. $^{8}$

Finally, in order to analyse the role played by the industrial relations regime, we estimate equation $\left(7^{\prime}\right)$ :

$$
\begin{aligned}
\ln _{\text {va_hour }}=\theta & \ln \text { va_hour }{ }_{\mathrm{jt}-1}+\beta_{1} \sigma_{\mathrm{jt}-1}+\beta_{2}[\sigma * \text { Firm_Agreement }]_{\mathrm{jt}-1} \\
& +\beta_{3}\left[\sigma * \mathrm{D}_{1}\right]_{\mathrm{jt}-1}+\beta_{4}\left[\sigma * \mathrm{D}_{1} * \text { Firm_Agreement }\right]_{\mathrm{jt}-1} \\
& +\beta_{5}\left[\sigma * \mathrm{D}_{2}\right]_{\mathrm{jt}-1}+\beta_{6}\left[\sigma * \mathrm{D}_{2} * \text { Firm_Agreement }\right]_{\mathrm{jt}-1} \\
& +\beta_{7} \text { Firm_Agreement }{ }_{\mathrm{jt}-1}+\mathbf{x}_{\mathbf{j t}} \boldsymbol{\beta}_{8}+\mathbf{z}_{\mathbf{j t}} \boldsymbol{\beta}_{9}+\delta_{\mathrm{j}}+\gamma_{\mathrm{t}}+\omega_{\mathrm{jt}}
\end{aligned}
$$

where 'Firm_Agreement' is a dummy variable that is equal to one if the firm is covered by a firm-level collective agreement (and zero if the firm is solely covered by an industry agreement). ${ }^{9}$

\section{Data set}

Our empirical analysis is based on a combination of two large data sets covering the years 1999-2006. The first, carried out by Statistics Belgium, is the 'Structure of Earnings Survey' (SES). It is representative of all firms operating in Belgium that employ at least 10 workers and with economic activities within sections $\mathrm{C}$ to $\mathrm{K}$ of the NACE Rev. 1 nomenclature ${ }^{10}$. The survey contains a wealth of information, provided by the management of firms, both on the characteristics of the latter (e.g. sector of activity, number of workers, level of collective wage bargaining) and on the individuals working there (e.g. age, education, tenure, gross earnings,

\footnotetext{
${ }^{8}$ The 'low educational level' includes workers who have attained lower secondary qualifications at most and the 'low ability occupation' includes workers whose occupations fall into groups 7 to 9 from the International Standard Classification of Occupations (craft and related trades workers; plant and machine operators and assemblers; and elementary occupations).

${ }^{9}$ We also did the same exercise but starting from equation (6), i.e. by interacting respectively 'Low-Skilled' and 'Firm-Agreement' dummy variables with the wage dispersion indicators in level and squared. However, due to strong multicolinearity problems, this quadratic specification had to be abandoned.

${ }^{10}$ It thus covers the following sectors: i) mining and quarrying (C), ii) manufacturing (D), iii) electricity, gas and water supply (E), iv) construction (F), v) wholesale and retail trade, repair of motor vehicles, motorcycles and personal and household goods (G), vi) hotels and restaurants $(\mathrm{H})$, vii) transport, storage and communication (I), viii) financial intermediation (J), and ix) real estate, renting and business activities (K).
} 
paid hours, sex, occupation). ${ }^{11}$ Gross hourly wages are calculated by dividing gross earnings (including overtime payments, premiums for shift, night and/or weekend work and other bonuses) in the reference period by the corresponding number of total paid hours (including overtime). The SES provides no financial information. Therefore, it has been merged with a firm-level survey, the 'Structure of Business Survey' (SBS). The SBS, also conducted by Statistics Belgium, provides information on financial variables such as firm-level value added and gross operating surplus per hour worked. The coverage of the SBS differs from that of the SES in that it does not cover the whole financial sector (NACE J) but only Other Financial Intermediation (NACE 652) and Activities Auxiliary to Financial Intermediation (NACE 67). The merger of the SES and SBS datasets is very precise as it has been carried out by Statistics Belgium on the basis of firms' social security number.

The computation of our conditional wage dispersion indicator requires a sufficient number of individual observations per firm. We therefore eliminate firms with less than 10 observations in a given year. ${ }^{12}$ Moreover, we exclude workers and/or firms for which data are

\footnotetext{
${ }^{11}$ The SES is a stratified sample. The stratification criteria refer respectively to the region (NUTS-groups), the principal economic activity (NACE-groups) and the size of the firm. The sample size in each stratum depends on the size of the firm. Sampling percentages of firms are respectively equal to 10, 50 and $100 \%$ when the number of workers is between 10 and 50, between 50 and 99, and above 100. Within a firm, sampling percentages of employees also depend on size. Sampling percentages of employees reach respectively 100, 50, 25, 14.3 and $10 \%$ when the number of workers is between 10 and 20, between 20 and 50, between 50 and 99, between 100 and 199, and between 200 and 299. Firms employing 300 workers or more have to report information for an absolute number of employees. This number ranges between 30 (for firms with between 300 and 349 workers) and 200 (for firms with 12,000 workers or more). To guarantee that firms report information on a representative sample of their workers, they are asked to follow a specific procedure. First, they have to rank their employees in alphabetical order. Next, Statistics Belgium give them a random letter (e.g. the letter $\mathrm{O}$ ) from which they have to start when reporting information on their employees (following the alphabetical order of workers' names in their list). If they reach the letter $\mathrm{Z}$ and still have to provide information on some of their employees, they have to continue from the letter A in their list. Moreover, firms that employ different categories of workers, namely managers, blue- and/or white-collar workers, have to set up a separate alphabetical list for each of these categories and to report information on a number of workers in these different groups that is proportional to their share in total firm employment. For example, a firm with 300 employees (namely, 60 managers, 180 white-collar workers and 60 blue-collar workers) will have to report information on 30 workers (namely, 6 managers, 18 white-collar workers and 6 blue-collar workers). Finally, let us notice that no threshold at the upper limit of wages is found in the SES. To put it differently, wages are not censored. For an extended discussion see Demunter (2000).

12 Theoretically, the characteristics of the SES data set should guarantee that the minimum number of individual observations per firm and per year is equal to 10 (see footnote 11). However, in practice, in a very
} 
missing or inaccurate. We do therefore also not consider workers earning less than the minimum hourly wage and firms that present negative value added. ${ }^{13}$ Our final sample consists of an unbalanced panel of 20,613 firm-year-observations from 9,254 firms. It is representative of all firms employing at least 10 workers within sections $\mathrm{C}$ to $\mathrm{K}$ of the NACE Rev. 1 nomenclature, with the exception of large parts of the financial sector (NACE J) and the electricity, gas and water supply industry (NACE E). However, given that sampling percentages of firms in our data set increase with the size of the latter (see footnote 11), medium-sized and large firms are over-represented in econometric specifications requiring firm information on (at least) two consecutive years. ${ }^{14}$

\section{[Insert Table 2]}

Table 2 depicts the means and standard deviations of the main variables. It indicates that we are looking at firms employing 126 workers on average with a mean gross hourly wage (including bonuses) of 15.98 euros and a conditional hourly wage dispersion of 0.15 euro. ${ }^{15}$ We also observe that the average value added per hour worked amounts to 55.17 euros, and that around $26 \%$ of the workers are women, $57 \%$ are blue collars and $38 \%$ have a low level of education (i.e. lower secondary school at most). Firms are essentially concentrated in the manufacturing sector $(46 \%)$, wholesale and retail trade, repair of motor vehicles, motorcycles and personal and household goods (17\%), construction (13\%) and in real estate, renting and business activities (12\%).

small number of cases this minimum number of data points is not reached. This could be explained for instance by the fact that some firms did not fill in the questionnaire for a sufficient number of their employees or because some questionnaires have been lost or not encoded by the administration.

${ }^{13}$ These selection criteria are not likely to affect our results as they lead to a small drop in sample size.

${ }^{14}$ Appendix 2 shows how descriptive statistics evolve when only selecting firms observed during at least two consecutive years. As expected, selected firms employ a larger number of workers and present the usual features associated to their bigger size such as higher wages and productivity, a stronger concentration in the manufacturing sector and a higher incidence of collective agreements at the firm level.

${ }^{15}$ In contrast, the average unconditional hourly wage dispersion (i.e. the standard deviation of gross hourly wages within each firm) amounts to 5.03 euros, which thus emphasizes that considerable heterogeneity is encompassed by our conditional indicator. 


\section{Results}

\subsection{Overall relation}

We first estimate equation (2) by OLS. Results presented in column 2 of Table 3 point towards the existence of a positive and significant relationship between wage dispersion and firm productivity. Indeed, the point estimate amounts to 1.45 and yields an elasticity of 0.22 at the sample mean.

\section{[Insert Table 3]}

This positive impact of wage dispersion on firm productivity tends to support the incentive effect predicted for instance by the 'tournament' model. We can, however, assume that the relationship could in fact be hump-shaped. Indeed, an overly small wage dispersion level might be harmful for firm productivity due to a lack of appropriate incentives. But excessive wage dispersion might also negatively affect productivity because of 'fairness' and/or 'sabotage' issues.

To test for a hump-shaped relationship, we first add the wage dispersion indicator in quadratic form to equation (2). Findings reported in column 3 of Table 3 show that the coefficient of wage dispersion in level is again positive and significant and that the wage dispersion indicator in quadratic form presents a significant negative coefficient. So evidence appears in favour of a hump-shaped relationship between wage dispersion and productivity. The results in Table 3 also allow to estimate that productivity is the greatest when the conditional wage dispersion indicator amounts to 1.29 euros. However, the value of this turning point should be interpreted with care given i) that it is lying outside of the range of the explanatory variable and ii) a multicolinearity problem, i.e. a strong correlation between the wage dispersion variables in level and squared. We also examine the existence of a non-linear relationship between wage dispersion and firm productivity by interacting the wage dispersion indicator with two dummy variables capturing the size of intra-firm wage inequality. Results based on this specification do not support the hump-shaped hypothesis (see column 4 of Table 3 ).

Be that as it may, findings reported so far should be assessed with caution given that they are subject to several methodological limitations. A first one is related to the potential 
simultaneity between wage dispersion and firm productivity. To examine the presence of such a problem, we apply Davidson and MacKinnon's (1989, 1993) version of the Hausman (1978) test. The result of this test, shown in column 2 of Table 3, indicates that wage dispersion is endogenously determined. Above-mentioned OLS results are thus inconsistent. To account for this issue, we estimate equation (3) using the first lag of the wage dispersion indicator rather than its current value as our main explanatory variable. Findings based on this specification are reported in columns 5 to 7 of Table 3. They support the existence of a humpshaped relationship between wage dispersion and firm productivity. However, the Hausman (1978) test still rejects the null hypothesis of consistent OLS estimates (see column 5 of Table $3)$.

Our results still suffer from the fact that time-invariant workplace characteristics are not controlled for. Therefore, we estimate a firm fixed-effects model using one year lagged wage dispersion as our main explanatory variable (equation (4)). We thus examine how changes in lagged wage dispersion affect changes in current productivity within firms. Results, presented in columns 2 to 4 of Table 4, show that the regression coefficient for the wage dispersion indicator (in level) decreases sharply after controlling for firm fixed-effects. However, it remains positive and significant (see column 2). In addition, the Hausman (1978) test now indicates that the hypothesis of exogeneity of wage dispersion cannot be rejected. Turning to the specification including the wage dispersion indicator in level and squared (see column 3), we find that both regression coefficients are positive and not significant. Yet, these results should be interpreted with care given the aforementioned multicolinearity problem. Furthermore, findings based on our alternative specification (i.e. including wage inequality in interaction with dummy variables) support the hump-shaped hypothesis. Indeed, they show that the elasticity is significantly positive, but that its magnitude decreases sharply when a relatively high level of wage inequality is attained (i.e. above the $66^{\text {th }}$ percentile of intra-firm wage inequality).

\section{[Insert Table 4]}

Another improvement in the analysis of the relationship between wage dispersion and firm productivity can be achieved by considering the potential state dependence of the productivity variable. To do so, we estimate equation (5) using the dynamic system GMM estimator which: i) controls for time-invariant heterogeneity of firms, ii) addresses the simultaneity problem using more instruments than in previous specifications, and iii) takes the likely state 
dependence of firm productivity into account. Results are presented in columns 5 to 7 of Table 4. To examine their reliability, we first apply the Hansen (1982) test of overidentifying restrictions and Arellano-Bond's test for second-order autocorrelation in the first-differenced errors. As shown in Table 4, they respectively do not reject the null hypothesis of valid instruments and of no autocorrelation. As expected, we also find that current productivity is to a significant and important extent related to its past value. However, results still support the existence of a hump-shaped relationship between wage dispersion and firm productivity (see column 7 of Table 4). Results reported in the last column of Table 4 further allow to estimate that the elasticity between (one year lagged) wage dispersion and productivity is equal to 0.21 at sample mean. ${ }^{16}$ This value, in the range of the OLS and fixed effects estimates, suggests that, on average, a rise of $10 \%$ in (one year lagged) wage dispersion increases firm productivity by $2.1 \%$.

\subsection{Workforce skill level and industrial relations regime}

In this section, we investigate whether the relationship between wage dispersion and firm productivity depends on: i) the skill level of the workforce, and ii) the industrial relations regime. To do so, we estimate respectively equations (7) and (7') using the dynamic system GMM estimator. Results are reported in Table 5. For all working environments, the Hansen (1982) test of overidentifying restrictions and the Arellano-Bond's test for second-order autocorrelation in the first-differenced errors again respectively do not reject the null hypothesis of valid instruments and of no autocorrelation. In addition, findings show the existence of a significant hump-shaped relationship between wage dispersion and firm productivity, whatever the skill level of the workforce and the level of wage bargaining.

\section{[Insert Table 5]}

Results, reported in the second column of Table 5, further indicate that the effect of wage dispersion on firm productivity is significantly larger for firms with a highly skilled

\footnotetext{
${ }^{16}$ The sample mean value of intra-firm wage dispersion is equal to 0.16 . This value lies between the $33^{\text {rd }}$ and the $66^{\text {th }}$ percentiles of the distribution of intra-firm wage inequality across firms. As a result the elasticity at sample mean is obtained by multiplying 0.16 by the sum of the regression coefficients associated respectively to the wage dispersion variable in level (3.08) and to the wage dispersion indicator interacted with the appropriate dummy $\mathrm{D}_{1}(-1.74)$. Put differently, $0.21=0.16 *(3.08+(-1.74))$.
} 
workforce, i.e. for firms with a small proportion of low-skilled workers. These results tend to support Barth et al. (2008), Foss and Laursen (2005) and Prendergast's (2002) arguments. Indeed, they might be explained by the fact that highly skilled workers are more costly to monitor and can increase their productivity more easily than their low-skilled counterparts. Moreover, they are in line with earlier results obtained by Mahy et al. (2010) on the basis of cross-sectional data for the Belgian economy.

As regards the industrial relations regime, no significant difference is found in the elasticity between productivity and wage dispersion between firms that are solely covered by an industry collective agreement and firms in which wages are collectively renegotiated (see results in the third column of Table 5). This finding suggests that the efficiency of performance pay schemes (measured through their impact on productivity) does not depend on whether wages are collectively renegotiated at the firm level. Put differently, it does not seem to support the hypothesis that firms solely covered by centralised bargaining (i.e. industry collective agreements) face additional difficulties to implement a coherent internal wage policy, with effective differential rewards. This could be explained by the fact that these firms still have the possibility to change their pay structure at the company level through individual bargaining or unilateral employers' decisions. It should also be recalled that firmlevel collective agreements in Belgium always complement industry agreements. Moreover, the wage bargained at the firm level can only be greater than or equal to the wage set at the industry level. Therefore, industry agreements are likely to constrain similarly the wage policy of all firms, whether or not covered by a company collective agreement. Findings also tend to suggest that factors such as information, commitment, consensus and certainty in the evaluation process, which are expected to enhance productivity effects of wage inequality (Pfeffer and Langton, 1993), are not more present in firms where performance pay systems are negotiated with trade unions at the company level. Moreover, the ability to renegotiate wages at this level does not seem to improve the degree of trust in the relations between management and employees. Indeed, results suggest that pay-for-performance systems have the same efficiency in firms solely covered by an industry agreement, i.e. in firms where such systems are introduced following an independent decision of the management or individual negotiations. 


\section{Conclusion}

Firms try to design appropriate incentive mechanisms to optimize workers' productivity. In this context, relative wages are often considered to play a determinant role. If workers compare their wages with those of their co-workers when choosing their level of effort, wage dispersion at the firm level becomes a crucial variable for explaining workers' productivity and firm performance.

Theoretical predictions regarding the impact of wage dispersion on firm productivity are quite controversial. In the context of performance-related pay systems based on relative criteria, the 'tournament' model (Lazear and Rosen, 1981) stresses that a more differentiated wage structure stimulates workers' effort through the incentive resulting from awarding the largest prize to the most productive worker. However, Lazear $(1989,1995)$ later showed in his 'industrial politics and sabotage' model that the tournament theory might also sometimes require wage compression. Moreover, other theories argue that wage compression reinforces workers' productivity by either improving labour relations (Akerlof and Yellen, 1988), sustaining and stimulating cohesiveness among the workforce (Levine, 1991) or preventing workers from engaging in costly rent-seeking activities instead of productive work (Milgrom and Roberts, 1990).

Given the importance of this issue and the ambiguity of theoretical predictions, empirical tests are needed to discriminate among opposing hypotheses. Yet, the empirical literature on intra-firm wage dispersion and firm productivity is very inconclusive. Moreover, the validity of most results is difficult to assess due to various methodological and/or data limitations (i.e. in terms of indicators used, data coverage or estimation strategy). In addition, studies considering that this relationship might be influenced by specific working environments are not numerous.

Therefore, the aim of this paper is twofold. First, it puts the relationship between wage dispersion and firm productivity to an updated test, taking advantage of access to detailed Belgian LEE panel data for the years 1999-2006. Our paper contributes significantly to the existing literature as it is the first, as far as we know, to simultaneously: i) focus on a large part of the private sector, ii) use both a conditional wage dispersion indicator and accurate information on firm productivity, namely the average value added per hour worked, iii) control for the endogeneity of wage dispersion (which can arise from the potential 
simultaneity between the latter and productivity) and for time-invariant workplace characteristics, and iv) adopt a dynamic specification to control for the potential state dependence of the productivity measure. Next, this paper examines whether the relationship between wage dispersion and firm productivity varies across different working environments. More precisely, it investigates the interaction with the skills of the workforce and the industrial relations regime. To our knowledge, the second issue has so far only been empirically explored by Jirjahn and Kraft (2007) with German data.

Results based on our preferred specification show the existence of a significant humpshaped relationship between wage dispersion and firm productivity for all working environments under investigation. They thus suggest that the incentive effect of wage dispersion, predicted for instance by the 'tournament' model, dominates 'fairness' and/or 'sabotage' considerations, though the latter become increasingly important as wage dispersion rises.

Moreover, we find that the intensity of the relationship between wage dispersion and firm productivity is stronger among firms with a larger proportion of highly skilled workers. This might be explained by the fact that monitoring costs and production-effort elasticity are greater for those workers. In contrast, the impact of wage dispersion on firm productivity is not found to depend on whether wages are collectively renegotiated at the firm level. This finding may suggest that factors such information, commitment, consensus and certainty in the evaluation process, which are expected to enhance productivity effects of wage inequality (Pfeffer and Langton, 1993), are not more present in firms where performance pay systems are negotiated with trade unions at the company level. Moreover, it does not seem to support the hypothesis that firms solely covered by centralised bargaining (i.e. industry collective agreements) face additional difficulties to implement a coherent internal wage policy, with effective differential rewards. 


\section{References}

Akerlof, G and Yellen, J (1988), Fairness and unemployment. American Economic Review (Papers and Proceedings), 78, pp 44-49.

Arellano, M and Bover, O (1995), Another look at the instrumental variable estimation of error-components models. Journal of Econometrics, 68, pp 29-51.

Bandiera, O, Barankay, I and Rasul, I (2005), Social preferences and the response to incentives: evidence from personnel data. Quarterly Journal of Economics, 120, pp 917-962.

Barth, E, Bratsberg, B, Haegeland, T and Raaum, O (2008), Who pays for performance. International Journal of Manpower, 29, pp 8-29.

Beaumont, P and Harris, R (2003), Internal wage structure and organizational performance. British Journal of Industrial Relations, 41, pp 53-70.

Belfield, R and Marsden, D (2003), Performance pay, monitoring environments, and establishment performance. International Journal of Manpower, 24, pp 452-471.

Bingley, P and Eriksson, T (2001), 'Pay spread and skewness, employee effort and firm productivity'. Working paper (Department of Economics, Faculty of Business Administration, Aarhus, Denmark) 01-2.

Bloom, M (1999), The performance effects of pay dispersion on individuals and organizations. Academy of Management Journal, 42, pp 25-40.

Blundell, R and Bond, S (1998), Initial conditions and moment restrictions in dynamic panel data models. Journal of Econometrics, 87, pp 115-143.

Bond, S (2002), Dynamic panel data models: a guide to micro data methods and practice. Portuguese Economic Journal, 1, pp 141-162.

Braakmann, N (2008), 'Intra-firm wage inequality and firm performance - First evidence from German linked employer-employee-data'. Working paper 77 (Series in Economics, University of Lüneburg, Germany).

Brown, C (1990), Firms' choice of method of pay. Industrial and Labor Relations Review, 43, pp 165-182.

Bryson, A, Forth, J and Kirby, S (2005), High-involvement management practices, trade union representation and workplace performance in Britain. Scottish Journal of Political Economy, 52, pp 451-491. 
Cowherd, D and Levine, D (1992), Product quality and pay equity between lower-level employees and top management: an investigation of distributive justice theory. Administrative Science Quarterly, 37, pp 302-320.

Davidson, R and MacKinnon, J (1989), Testing for consistency using artificial regressions. Econometric Theory, 5, pp 364-384.

Davidson, R and MacKinnon, J (1993), Estimation and Inference in Econometrics. Oxford: Oxford University Press.

DeBrock, L, Hendricks, W and Koenker, R (2004), Pay and performance: the impact of salary distribution on firm-level outcomes in baseball. Journal of Sports Economics, 5, pp 243261.

Demunter, C (2000), 'Structure and distribution of earnings survey: analysis 1995'. Statistics Belgium working paper.

Doucouliagos, C and Laroche, P (2003), What do unions do to productivity? A meta-analysis. Industrial Relations, 42, pp 650-691.

Eriksson, T (1999), Executive compensation and tournament theory: empirical tests on Danish data. Journal of Labor Economics, 17, pp 262-280.

Freeman, R (1982), 'Union wage practices and wage dispersion within establishments'. NBER working paper 752.

Frick, B, Prinz J and Winkelmann, K (2003), Pay inequalities and team performance: empirical evidence from the North American major leagues. International Journal of Manpower, 24, pp 472-488.

Gomez, R (2002), Salary compression and team performance: evidence from the national hockey league. Zeitschrift für Betrebswirtschaf, 72, pp 203-220.

Grund, C and Westergaard-Nielsen, N (2008), The dispersion of employees' wage increases and firm performance. Industrial and Labor Relations Review, 61, pp 485-501.

Hansen, L (1982), Large sample properties of generalized method of moments estimators. Econometrica, 50, pp 1029-1054.

Harder, J (1992), Play for pay: effects of inequity in a pay-for-performance context. Administrative Science Quarterly, 37, pp 321-335.

Hausman, J (1978), Specification tests in econometrics. Econometrica, 46, pp 1251-1272.

Heyman, F (2005), Pay inequality and firm performance: evidence from matched employeremployee data. Applied Economics, 37, pp 1313-1327. 
Heywood, J S and Jirjahn, U (2006), Performance pay: determinants and consequences. in Lewin, D (ed.), Contemporary Issues in Industrial Relations. LERA Research Volume, Labor and Employment Relations Association: Champaign IL, pp 149-188.

Hibbs, D and Locking, H (2000), Wage dispersion and productive efficiency: evidence for Sweden. Journal of Labor Economics, 18, pp 755-782.

Hunnes, A (2009), Internal wage dispersion and firm performance: white-collar evidence. International Journal of Manpower, 30, pp 776-796.

Jirjahn, U and Kraft, K (2007), Intra-firm wage dispersion and firm performance - Is there a uniform relationship? Kyklos, 60, 231-253.

Koubi, A and Roux, S (2006), 'Une réinterprétation de la relation entre productivité et inégalités salariales dans les entreprises'. Série des Documents de Travail de la Direction des Etudes et Synthèses Economiques, 13, INSEE.

Lallemand, T, Plasman, R and Rycx, F (2007), 'Wage structure and firm productivity in Belgium'. NBER working paper 12978.

Lazear, E (1989), Pay equality and industrial politics. Journal of Political Economy, 97, pp 561-580.

Lazear, E (1995), Personnel Economics. Cambridge (Mass.): MIT Press.

Lazear, E and Rosen, S (1981), Rank-order tournaments as optimum labor contracts. Journal of Political Economy, 89, pp 841-864.

Lemieux, T, MacLeod, B and Parent, D (2009), Performance pay and wage inequality. The Quarterly Journal of Economics, 124, pp 1-49.

Leonard, J (1990), Executive pay and firm performance. Industrial and Labor Relations Review, 43, pp 13-29.

Levine, D (1991), Cohesiveness, productivity and wage dispersion. Journal of Economic Behavior and Organization, 15, pp 237-255.

Mahy, B, Rycx, F and Volral, M (2010), Wage dispersion and firm productivity in different working environments. British Journal of Industrial Relations, forthcoming.

Main, B, O'Reilly, C and Wade, J (1993), Top executive pay: tournament or teamwork? Journal of Labor Economics, 11, pp 606-628.

Martins, P (2008), Dispersion in wage premiums and firm performance. Economics Letters, 101, pp 63-65.

McNabb, R and Whitfield, K (2003), 'Varying types of performance related pay and productivity performance'. Unpublished manuscript (Cardiff Business School, Cardiff university). 
Milgrom, P (1988), Employment contracts, influence activities and efficient organisation design. Journal of Political Economy, 96, pp 42-60.

Milgrom, P and Roberts, J (1990), The efficiency of equity in organisational decision processes. American Economic Review (Papers and Proceedings), 80, pp 154-159.

OECD (2004), Employment Outlook. Paris: OECD.

Pfeffer, J and Langton, N (1993), The effect of wage dispersion on satisfaction, productivity, and working collaboratively: evidence from college and university faculty. Administrative Science Quarterly, 38, pp 382-407.

Prendergast, C (2002), The tenuous trade-off between risk and incentives. Journal of Political Economy, 110, pp 1071-1102.

Richards, D and Guell, R (1998), Baseball success and the structure of salaries. Applied Economics Letters, 5, pp 291-296.

Schöttner, A and Thiele, V (2007), 'Promotion tournaments and individual performance pay'. SFB discussion paper 649, Humboldt University.

van Ours, J and Stoeldraijer, L (2010), 'Age, wage and productivity'. IZA discussions paper 4765.

White, H (1980), A heteroscedasticity-consistent covariance matrix estimator and a direct test for heteroscedasticity. Econometrica, 48, pp 817-830.

Winter-Ebmer, R and Zweimüller, J (1999), Intra-firm wage dispersion and firm performance. Kyklos, 52, pp 555-572. 
Table 1. Studies on broad occupational groups and industries that do control for firm fixed effects

\begin{tabular}{|c|c|c|c|c|c|c|c|}
\hline Study & Country & Data / Coverage & $\begin{array}{l}\text { Conditional } \\
\text { wage } \\
\text { dispersion }\end{array}$ & $\begin{array}{l}\text { Firm performance } \\
\text { indicator }\end{array}$ & $\begin{array}{l}\text { Control for } \\
\text { simultaneity }\end{array}$ & $\begin{array}{l}\text { Control for } \\
\text { state } \\
\text { dependence }\end{array}$ & Results \\
\hline $\begin{array}{l}\text { Winter-Ebmer and } \\
\text { Zweimüller (1999) }\end{array}$ & Austria & $\begin{array}{l}\text { Panel data on } 130 \\
\text { firms, 1975-91 }\end{array}$ & Yes & $\begin{array}{l}\text { Standardized wages } \\
\text { for white- and blue- } \\
\text { collar workers }\end{array}$ & No & No & $\begin{array}{l}\text { OLS: hump-shaped relationship for both } \\
\text { white- and blue-collar workers } \\
\text { Fixed-effects: no significant impact for } \\
\text { blue-collar workers and flatter hump- } \\
\text { shaped relationship for white-collar } \\
\text { workers }\end{array}$ \\
\hline $\begin{array}{l}\text { Beaumont and Harris } \\
\text { (2003) }\end{array}$ & UK & $\begin{array}{l}\text { Panel data on firms } \\
\text { in } 5 \text { industrial } \\
\text { sectors, 1978-95 } \\
\end{array}$ & No & $\begin{array}{l}\text { Value added per } \\
\text { worker }\end{array}$ & Yes & Yes & $\begin{array}{l}G M M \text { : negative (positive) impact of } \\
\text { wage dispersion on firm performance in } \\
1 \text { (4) sector(s). }\end{array}$ \\
\hline Heyman (2005) & Sweden & $\begin{array}{l}\text { Panel data for white- } \\
\text { collar workers and } \\
\text { managers in private } \\
\text { sector firms, } 1991 \\
\text { and } 1995\end{array}$ & $\begin{array}{l}\text { Yes (for } \\
\text { white collar } \\
\text { workers) }\end{array}$ & Profits per employee & Yes & No & $\begin{array}{l}\text { OLS, 2SLS and first-differences: } \\
\text { positive impact for white-collar workers } \\
\text { and managers }\end{array}$ \\
\hline $\begin{array}{l}\text { Koubi and Roux } \\
(2006)\end{array}$ & France & $\begin{array}{l}\text { Panel data on } 60551 \\
\text { firms, 1994-2002 }\end{array}$ & Yes & $\begin{array}{l}\text { Value added per } \\
\text { worker and gross } \\
\text { operation surplus } \\
\text { divided by capital }\end{array}$ & Yes & No & $\begin{array}{l}\text { OLS, long differences, GMM : positive } \\
\text { impact of wage dispersion on } \\
\text { productivity in most sectors } \\
\text { investigated }\end{array}$ \\
\hline Braakmann (2008) & $\begin{array}{l}\text { (West) } \\
\text { Germany }\end{array}$ & $\begin{array}{l}\text { Panel data on } 11,000 \\
\text { firms, } 1995-2005\end{array}$ & Yes & Sales per worker & Yes & Yes & $\begin{array}{l}\text { Fixed-effects / GMM: negative or U- } \\
\text { shaped / insignificant relationship }\end{array}$ \\
\hline $\begin{array}{l}\text { Grund and } \\
\text { Westergaard-Nielsen } \\
(2008)\end{array}$ & Denmark & $\begin{array}{l}\text { Panel data on 5,736 } \\
\text { firms, 1992-97 }\end{array}$ & No & $\begin{array}{l}\text { Value added per } \\
\text { employee }\end{array}$ & No & Yes & $\begin{array}{l}\text { OLS / Fixed effects: hump-shaped / no } \\
\text { significant relationship between } \\
\text { dispersion in wage levels and firm } \\
\text { productivity }\end{array}$ \\
\hline Martins (2008) & Portugal & $\begin{array}{l}\text { Panel data on } 4,735 \\
\text { firms, 1991-2000 }\end{array}$ & Yes & Sales per worker & No & No & $\begin{array}{l}\text { OLS / Fixed effects: positive / negative } \\
\text { relationship }\end{array}$ \\
\hline Hunnes (2009) & Norway & $\begin{array}{l}\text { Panel data covering } \\
\text { white-collar workers } \\
\text { (only full-time) in } \\
\text { 1,723 firms, 1986-97 }\end{array}$ & Yes & $\begin{array}{l}\text { Gross production } \\
\text { value and profits per } \\
\text { employee }\end{array}$ & Yes & No & $\begin{array}{l}\text { OLS / Fixed effects: positive / no } \\
\text { significant relationship between the } \\
\text { dispersion in the fixed component of } \\
\text { wages and firm performance } \\
\text { No robust relationship between bonus } \\
\text { payments and firm performance }\end{array}$ \\
\hline
\end{tabular}

Note: For more detailed results see Appendix 1. 
Table 2. Descriptive statistics of selected variables

\begin{tabular}{|c|c|c|}
\hline Variables: & Mean & Std. Dev. \\
\hline Hourly value added $\left(€^{l}\right)$ & 55.17 & 500.8 \\
\hline Gross hourly wage $\left(€^{l}\right)$ & 15.98 & 5.76 \\
\hline Gross monthly wage $\left(€^{l}\right)$ & 2476.93 & 929.27 \\
\hline \multicolumn{3}{|l|}{ Intra-firm wage dispersion $\left(€^{l}\right)$ : } \\
\hline Conditional wage dispersion ${ }^{2}$ & 0.15 & 0.09 \\
\hline Unconditional standard deviation of wages ${ }^{3}$ & 5.03 & 7.49 \\
\hline Size of the firm (number of workers) & 125.58 & 355.17 \\
\hline \multicolumn{3}{|l|}{ Age $(\%)$} \\
\hline Less than 25 years & 9.12 & 10.31 \\
\hline Between 25 and 49 years & 75.22 & 13.71 \\
\hline 50 years and more & 15.66 & 12.89 \\
\hline Women $(\%)$ & 26.15 & 24.29 \\
\hline \multicolumn{3}{|l|}{ Education (\%): } \\
\hline No degree, primary/lower secondary & 37.96 & 34.66 \\
\hline General upper secondary, technical/artistic/prof. upper secondary & 39.68 & 30.52 \\
\hline Higher non university, university and post graduate & 22.36 & 26.55 \\
\hline Blue-collar workers ${ }^{4}(\%)$ & 57.14 & 35.13 \\
\hline Firm-level collective agreement $(\%)$ & 16.92 & 37.49 \\
\hline \multicolumn{3}{|l|}{ Sector $(\%)$ : } \\
\hline Mining and quarrying $(\mathrm{C})$ & 0.37 & \\
\hline Manufacturing (D) & 45.57 & \\
\hline Electricity, gas and water supply (E) & 0.07 & \\
\hline Construction $(\mathrm{F})$ & 13.19 & \\
\hline $\begin{array}{l}\text { Wholesale and retail trade, repair of motor vehicles, motorcycles } \\
\text { and personal and household goods }(\mathrm{G})\end{array}$ & 17.01 & \\
\hline Hotels and restaurants $(\mathrm{H})$ & 2.77 & \\
\hline Transport, storage and communication (I) & 7.9 & \\
\hline Financial intermediation $(\mathrm{J})$ & 1.04 & \\
\hline Real estate, renting and business activities $(\mathrm{K})$ & 12.1 & \\
\hline Number of observations & \multicolumn{2}{|c|}{20,613} \\
\hline Number of firms & \multicolumn{2}{|c|}{9,254} \\
\hline \multicolumn{3}{|c|}{$\begin{array}{l}\text { At } 2006 \text { constant prices. }{ }^{2} \text { Hourly residual wage dispersion after controlling for human capital variables and } \\
\text { workers' characteristics in the wage equation following the Winter-Ebmer and Zweimüller (1999) methodology } \\
\text { (i.e. standard deviations of residuals of wage regressions run for each firm and each year separately). }{ }^{3} \text { Standard } \\
\text { deviation of gross hourly wages within each firm. }{ }^{4} \text { The distinction between blue- and white-collar workers is } \\
\text { based on the International Standard Classification of Occupations (ISCO-88). Workers belonging to groups } 1 \text { to } \\
5 \text { are considered to be white-collar workers (1: Legislators, senior officials and managers; } 2 \text { : Professionals; } 3 \text { : } \\
\text { Technicians and associate professionals; } 4 \text { : Clerks; } 5 \text { : Service workers and shop and market sales workers) and } \\
\text { those from groups } 7 \text { to } 9 \text { are considered to be blue-collar workers ( } 7 \text { : Craft and related trades workers; } 8 \text { : Plant } \\
\text { and machine operators and assemblers; } 9 \text { : Elementary occupations). }\end{array}$} \\
\hline
\end{tabular}


Table 3. Wage dispersion and firm productivity: OLS results

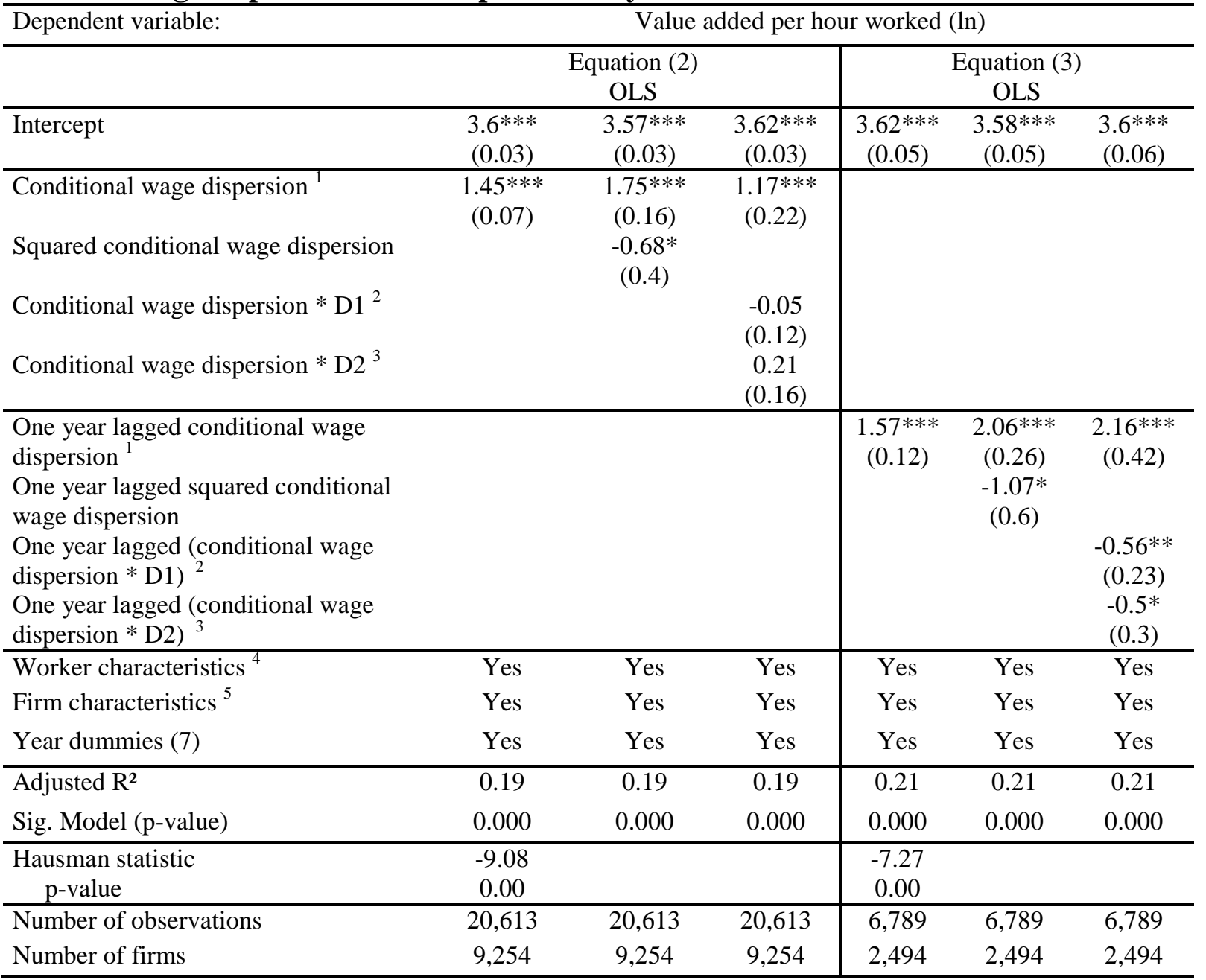

Notes: $* * * * * / *$ significant at the 1,5 and $10 \%$ level, respectively. Robust standard errors are shown in brackets.

${ }^{1}$ Hourly residual wage dispersion after controlling for human capital variables and workers' characteristics in the wage equation following the Winter-Ebmer and Zweimüller (1999) methodology (i.e. standard deviations of residuals of wage regressions run for each firm and each year separately).

${ }^{2} \mathrm{D}_{1}$ is a dummy variable that is equal to one if intra-firm wage dispersion ranges between the $33^{\text {rd }}$ and the $66^{\text {th }}$ percentiles of the distribution of intra-firm wage inequality across firms.

${ }^{3} \mathrm{D}_{2}$ is a dummy variable that is equal to one if intra-firm wage dispersion is greater than or equal to the $66^{\text {th }}$ percentile of the distribution of intra-firm wage inequality across firms.

${ }^{4}$ Share of the workforce that: i) has at most a degree of lower secondary education, ii) has at least 10 years of tenure, and iii) is younger than 25 and older than 49 years, respectively. The share of women and the share of blue-collar workers are also included.

${ }^{5}$ Sectoral affiliation (8 dummies), number of workers and level of wage bargaining (1 dummy). 
Table 4. Wage dispersion and firm productivity: Fixed-effects and GMM results

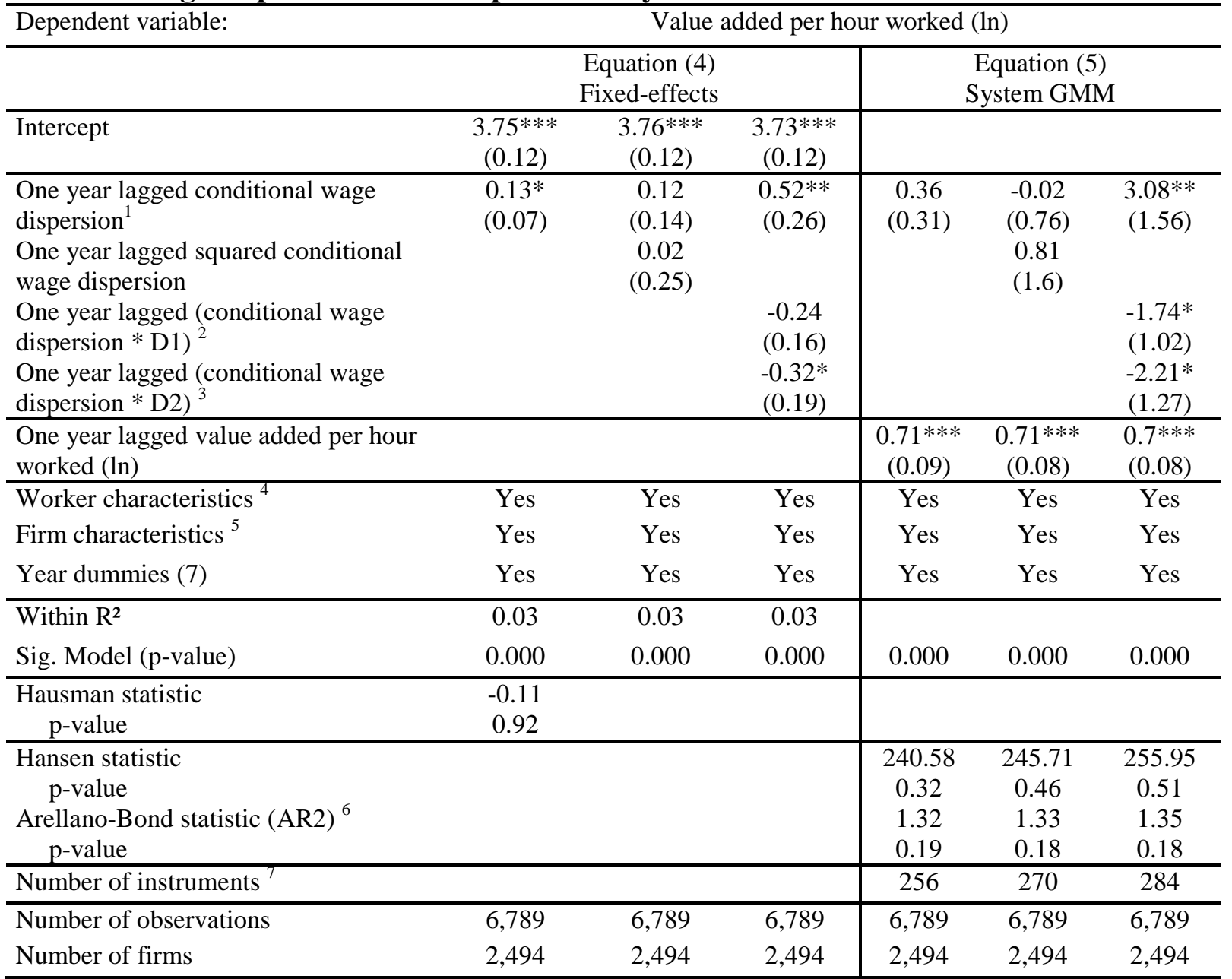

Notes: $* * * * * / *$ significant at the 1, 5 and $10 \%$ level, respectively. Robust standard errors are shown in brackets.

${ }^{1}$ Hourly residual wage dispersion after controlling for human capital variables and workers' characteristics in the wage equation following the Winter-Ebmer and Zweimüller (1999) methodology (i.e. standard deviations of residuals of wage regressions run for each firm and each year separately).

${ }^{2} \mathrm{D}_{1}$ is a dummy variable that is equal to one if intra-firm wage dispersion ranges between the $33^{\text {rd }}$ and the $66^{\text {th }}$ percentiles of the distribution of intra-firm wage inequality across firms.

${ }^{3} \mathrm{D}_{2}$ is a dummy variable that is equal to one if intra-firm wage dispersion is greater than or equal to the $66^{\text {th }}$ percentile of the distribution of intra-firm wage inequality across firms.

${ }^{4}$ Share of the workforce that: i) has at most a degree of lower secondary education, ii) has at least 10 years of tenure, and iii) is younger than 25 and older than 49 years, respectively. The share of women and the share of blue-collar workers are also included.

${ }^{5}$ Sectoral affiliation (8 dummies), number of workers and level of wage bargaining (1 dummy).

${ }^{6}$ AR2 displays the test for second-order autocorrelation in the first-differenced errors.

${ }^{7}$ Second and third lags of explanatory variables, excluding time dummies, are used as instruments. 
Table 5. Wage dispersion and firm productivity by workforce skill level and industrial relations regime

\begin{tabular}{|c|c|c|}
\hline \multirow[t]{2}{*}{ Dependent variable: } & \multicolumn{2}{|c|}{ Value added per hour worked (ln) } \\
\hline & Equation (7) & Equation (7’) \\
\hline & \multicolumn{2}{|c|}{ System GMM } \\
\hline One year lagged conditional wage dispersion ${ }^{1}$ & $\begin{array}{c}1.70 \text { *** } \\
(0.47)\end{array}$ & $\begin{array}{c}1.25 * * * \\
(0.43)\end{array}$ \\
\hline One year lagged (conditional wage dispersion $*$ D 1$)^{2}$ & $\begin{array}{c}-1.06 * * * \\
(0.27)\end{array}$ & $\begin{array}{c}-0.65 * * * \\
(0.25)\end{array}$ \\
\hline One year lagged (conditional wage dispersion $* \mathrm{D} 2)^{3}$ & $\begin{array}{c}-1.19 * * * \\
(0.35)\end{array}$ & $\begin{array}{c}-0.75^{* *} \\
(0.33) \\
\end{array}$ \\
\hline One year lagged (conditional wage dispersion * Low_Skilled) ${ }^{4}$ & $\begin{array}{l}-1.32 * \\
(0.73)\end{array}$ & \\
\hline One year lagged (conditional wage dispersion * D1 * Low_Skilled) & $\begin{array}{c}0.90 * * \\
(0.43)\end{array}$ & \\
\hline One year lagged (conditional wage dispersion $*$ D2 $*$ Low_Skilled) & $\begin{array}{c}0.86 \\
(0.57)\end{array}$ & \\
\hline One year lagged (conditional wage dispersion * Firm_Agreement) ${ }^{5}$ & & $\begin{array}{l}-0.46 \\
(0.75)\end{array}$ \\
\hline One year lagged (conditional wage dispersion $*$ D $1 *$ Firm_Agreement) & & $\begin{array}{c}0.15 \\
(0.46)\end{array}$ \\
\hline One year lagged (conditional wage dispersion $*$ D2 $*$ Firm_Agreement) & & $\begin{array}{c}0.14 \\
(0.58) \\
\end{array}$ \\
\hline One year lagged value added per hour worked $(\ln )$ & $\begin{array}{c}0.47 * * * \\
(0.08)\end{array}$ & $\begin{array}{c}0.48 * * * \\
(0.09)\end{array}$ \\
\hline Worker characteristics ${ }^{6}$ & Yes & Yes \\
\hline Firm characteristics ${ }^{7}$ & Yes & Yes \\
\hline Year dummies (7) & Yes & Yes \\
\hline Sig. Model (p-value) & 0.000 & 0.000 \\
\hline Hansen statistic & 368.54 & 337.86 \\
\hline $\mathrm{p}$-value & 0.16 & 0.29 \\
\hline Arellano-Bond statistic (AR2) ${ }^{8}$ & 1.47 & 1.45 \\
\hline $\mathrm{p}$-value & 0.14 & 0.15 \\
\hline Number of instruments ${ }^{9}$ & 373 & 354 \\
\hline Number of observations & 6,789 & 6,789 \\
\hline Number of firms & 2,494 & 2,494 \\
\hline
\end{tabular}

Notes: $* * * / * * / *$ significant at the 1, 5 and $10 \%$ level, respectively. Robust standard errors between brackets.

${ }^{1}$ Hourly residual wage dispersion after controlling for human capital variables and workers' characteristics in the wage equation following the Winter-Ebmer and Zweimüller (1999) methodology (i.e. standard deviations of residuals of wage regressions run for each firm and each year separately).

${ }^{2} \mathrm{D}_{1}$ is a dummy variable that is equal to one if intra-firm wage dispersion ranges between the $33^{\text {rd }}$ and the $66^{\text {th }}$ percentiles of the distribution of intra-firm wage inequality across firms.

${ }^{3} \mathrm{D}_{2}$ is a dummy variable that is equal to one if intra-firm wage dispersion is greater than or equal to the $66^{\text {th }}$ percentile of the distribution of intra-firm wage inequality across firms.

4 "Low_Skilled" is a dummy variable that is equal to one if the workforce of the firm is low-skilled (i.e. if the firm presents both a proportion of low-educated workers and a proportion of low-ability occupations larger than their respective medians on the whole sample, respectively 0.30 and 0.69 ).

5 "Firm_Agreement" is a dummy variable that is equal to one in the presence of a firm-level collective agreement (and zero if the firm is solely covered by an industry collective agreement).

${ }^{6}$ Share of the workforce that: i) has at most a degree of lower secondary education, ii) has at least 10 years of tenure, and iii) is younger than 25 and older than 49 years, respectively. The share of women and the share of blue-collar workers are also included.

7 Sectoral affiliation (8 dummies), number of workers, dummy "Low_Skilled" (only in model testing interaction with workforce skill level), and dummy "Firm_Agreement". Note that regression coefficients associated to the dummies "Low_Skilled" and "Firm_Agreement" are not significant at the 10 percent level.

${ }^{8}$ AR2 displays the test for second-order autocorrelation in the first-differenced errors.

${ }^{9}$ First and second lags of explanatory variables, excluding time dummies, are used as instruments. 
Appendix 1. Wage dispersion and firm performance: selected empirical studies

\begin{tabular}{|c|c|c|c|c|c|c|c|}
\hline Study & Country & Data / Coverage & $\begin{array}{l}\text { Wage dispersion } \\
\text { indicator }\end{array}$ & $\begin{array}{l}\text { Firm performance } \\
\text { indicator }\end{array}$ & $\begin{array}{l}\text { Estimation } \\
\text { method }\end{array}$ & $\begin{array}{l}\text { Control for } \\
\text { simultaneity / } \\
\text { state dependence }\end{array}$ & Results \\
\hline $\begin{array}{l}\text { Leonard } \\
(1990)\end{array}$ & US & $\begin{array}{l}\text { Panel data on executives } \\
\text { in } 439 \text { large corporations, } \\
1981-85\end{array}$ & $\begin{array}{l}\text { Unconditional: } \\
\text { standard deviation of } \\
\text { pay }\end{array}$ & Return on equity & $\begin{array}{l}\text { OLS and } \\
\text { fixed-effects }\end{array}$ & $\mathrm{No} / \mathrm{No}$ & No significant relationship \\
\hline $\begin{array}{l}\text { Cowherd and } \\
\text { Levine } \\
(1992)\end{array}$ & $\begin{array}{l}\text { North } \\
\text { America } \\
\text { and Europe }\end{array}$ & $\begin{array}{l}\text { Cross-sectional data on } \\
102 \text { business units in } 41 \\
\text { corporations }\end{array}$ & $\begin{array}{l}\text { Semi-conditional: } \\
\text { pay of hourly } \\
\text { employees relative to } \\
\text { the top three levels of } \\
\text { management, } \\
\text { controlling for the } \\
\text { input differential }\end{array}$ & $\begin{array}{l}\text { Product quality } \\
\text { (perceived by } \\
\text { consumers) }\end{array}$ & OLS & No / No & $\begin{array}{l}\text { Negative impact of wage dispersion on } \\
\text { firm performance }\end{array}$ \\
\hline $\begin{array}{l}\text { Harder } \\
(1992)\end{array}$ & US & $\begin{array}{l}\text { Cross-sectional data on } \\
\text { around } 350 \text { professional } \\
\text { baseball teams, } 4 \text { seasons } \\
(1976,1977,1987,1988) \\
\text { and on } 301 \text { professional } \\
\text { basketball teams, } 1 \text { season } \\
\text { (1987) }\end{array}$ & $\begin{array}{l}\text { Conditional: } \\
\text { two separate measures } \\
\text { of inequity (i.e. \% } \\
\text { overrewarded and } \\
\text { underrewarded players) }\end{array}$ & $\begin{array}{l}\text { Technical measures } \\
\text { for baseball (e.g. } \\
\text { runs created, total } \\
\text { average) and for } \\
\text { basketball (e.g. } \\
\text { points scored, } \\
\text { number of shots } \\
\text { attempted per } \\
\text { minute played) }\end{array}$ & $\begin{array}{l}\text { OLS, lagged } \\
\text { values of the } \\
\text { dependent } \\
\text { variable used } \\
\text { as control } \\
\text { variables }\end{array}$ & No / Yes & $\begin{array}{l}\text { Different responses to inequity measures: } \\
\text { Basketball: underreward leads to selfish } \\
\text { behaviour, overreward to cooperative } \\
\text { behaviour. } \\
\text { Baseball: results are less clear. }\end{array}$ \\
\hline $\begin{array}{l}\text { Main et al. } \\
\text { (1993) }\end{array}$ & US & $\begin{array}{l}\text { Panel data on executives } \\
\text { in } 210 \text { firms, } 1980-84\end{array}$ & $\begin{array}{l}\text { Unconditional: } \\
\text { coefficient of variation } \\
\text { of wages }\end{array}$ & $\begin{array}{l}\text { Return on assets } \\
\text { (ROA) and stock } \\
\text { market return }\end{array}$ & OLS & No / No & $\begin{array}{l}\text { Positive impact of wage dispersion on } \\
\text { ROA, no significant effect on the stock } \\
\text { market return }\end{array}$ \\
\hline $\begin{array}{l}\text { Pfeffer and } \\
\text { Langton } \\
\text { (1993) }\end{array}$ & US & $\begin{array}{l}\text { Cross-sectional data on } \\
\text { more than } 17,000 \text { college } \\
\text { and university professors } \\
\text { from more than } 600 \\
\text { academic departments, } \\
1969\end{array}$ & $\begin{array}{l}\text { Unconditional: } \\
\text { coefficient of variation } \\
\text { of wages }\end{array}$ & $\begin{array}{l}\text { Workers' } \\
\text { satisfaction, } \\
\text { research } \\
\text { productivity } \\
\text { (number of } \\
\text { publications), and } \\
\text { cooperation }\end{array}$ & OLS & No / No & $\begin{array}{l}\text { Negative impact of wage dispersion on } \\
\text { performance but magnitude depends on a } \\
\text { person's position in the salary structure, } \\
\text { information, commitment, consensus and } \\
\text { the level of certainty in the evaluation } \\
\text { process }\end{array}$ \\
\hline $\begin{array}{l}\text { Richards and } \\
\text { Guell (1998) }\end{array}$ & US & $\begin{array}{l}\text { Cross-sectional data on } \\
\text { professional baseball } \\
\text { teams, } 3 \text { seasons (1992, }\end{array}$ & $\begin{array}{l}\text { Unconditional: } \\
\text { variance of team } \\
\text { salaries }\end{array}$ & $\begin{array}{l}\text { Winning percentage } \\
\text { and probability to } \\
\text { win a title }\end{array}$ & $\begin{array}{l}\text { OLS and } \\
\text { probit }\end{array}$ & $\mathrm{No} / \mathrm{No}$ & $\begin{array}{l}\text { Negative effect of wage dispersion on the } \\
\text { winning percentage but no significant } \\
\text { impact on the probability to win a title }\end{array}$ \\
\hline
\end{tabular}




\begin{tabular}{|c|c|c|c|c|c|c|c|}
\hline & & 1993, 1995) & & & & & \\
\hline $\begin{array}{l}\text { Bloom } \\
(1999)\end{array}$ & $\begin{array}{l}\text { US and } \\
\text { Canada }\end{array}$ & $\begin{array}{l}\text { Panel data on } 29 \\
\text { professional baseball } \\
\text { teams }(1,644 \text { players }) \\
1985-93\end{array}$ & $\begin{array}{l}\text { Unconditional: } \\
\text { Gini coefficient, } \\
\text { coefficient of variation } \\
\text { of pay, difference } \\
\text { between the greatest } \\
\text { pay in a team and a } \\
\text { player's pay, ratio of a } \\
\text { player's pay to the } \\
\text { greatest pay in his team }\end{array}$ & $\begin{array}{l}\text { Winning } \\
\text { percentage, fan } \\
\text { attendance, team's } \\
\text { finishing position, } \\
\text { measures of } \\
\text { financial } \\
\text { performance (e.g. } \\
\text { total income, } \\
\text { franchise value). } \\
\text { Technical measures } \\
\text { of individual } \\
\text { players' } \\
\text { performance (e.g., } \\
\text { fielding runs, } \\
\text { pitching runs) }\end{array}$ & $\begin{array}{l}\text { Random- } \\
\text { effects }\end{array}$ & No / No & $\begin{array}{l}\text { Negative impact of pay dispersion on } \\
\text { players' and teams' performances }\end{array}$ \\
\hline $\begin{array}{l}\text { Eriksson } \\
\text { (1999) }\end{array}$ & Denmark & $\begin{array}{l}\text { Panel data on executives } \\
\text { in } 210 \text { firms, } 1992-95\end{array}$ & $\begin{array}{l}\text { Unconditional: } \\
\text { coefficient of variation } \\
\text { of wages }\end{array}$ & Profits/sales ratio & $\begin{array}{l}\text { OLS and } \\
\text { fixed-effects }\end{array}$ & No / No & $\begin{array}{l}\text { Weak positive impact of wage dispersion } \\
\text { on firm performance }\end{array}$ \\
\hline $\begin{array}{l}\text { Winter- } \\
\text { Ebmer and } \\
\text { Zweimüller } \\
\text { (1999) }\end{array}$ & Austria & $\begin{array}{l}\text { Panel data on } 130 \text { firms, } \\
1975-91\end{array}$ & $\begin{array}{l}\text { Conditional: } \\
\text { standard errors of wage } \\
\text { regressions }\end{array}$ & $\begin{array}{l}\text { Standardized wages } \\
\text { for white- and blue- } \\
\text { collar workers }\end{array}$ & $\begin{array}{l}\text { OLS, fixed- } \\
\text { and between- } \\
\text { effects }\end{array}$ & No / No & $\begin{array}{l}\text { OLS: hump-shaped relationship for both } \\
\text { white- and blue-collar workers (but } \\
\text { turning point at a higher level of wage } \\
\text { dispersion for blue-collar workers) } \\
\text { Fixed-effects: no significant impact for } \\
\text { blue-collar workers and flatter hump- } \\
\text { shaped relationship for white-collar } \\
\text { workers } \\
\text { Between-effects: same results as with } \\
\text { OLS }\end{array}$ \\
\hline $\begin{array}{l}\text { Hibbs and } \\
\text { Locking } \\
(2000)\end{array}$ & Sweden & $\begin{array}{l}\text { Aggregated individual } \\
\text { wage data, at plant (1972- } \\
\text { 93) and industry level } \\
(1963-93)\end{array}$ & $\begin{array}{l}\text { Unconditional: } \\
\text { squared coefficient of } \\
\text { variation of wages } \\
\text { among workers arrayed } \\
\text { by industries or plants, } \\
\text { decomposed in within } \\
\text { and between } \\
\text { components }\end{array}$ & $\begin{array}{l}\text { Real value added } \\
\text { and real value } \\
\text { added divided by } \\
\text { blue-collar hours }\end{array}$ & OLS & No / Yes & $\begin{array}{l}\text { Dispersion of wages within (between) } \\
\text { firms has a positive (negative) impact on } \\
\text { productivity }\end{array}$ \\
\hline Bingley and & Denmark & Panel data on 6,501 firms, & Conditional: & Total factor & OLS and & Yes (IV = & Productivity: hump-shaped relationship \\
\hline
\end{tabular}




\begin{tabular}{|c|c|c|c|c|c|c|c|}
\hline $\begin{array}{l}\text { Eriksson } \\
(2001)\end{array}$ & & $1992-95$ & $\begin{array}{l}\text { standard deviation and } \\
\text { skewness of the } \\
\text { residuals of wage } \\
\text { regressions }\end{array}$ & $\begin{array}{l}\text { productivity (Solow } \\
\text { residual of a Cobb- } \\
\text { Douglas production } \\
\text { function) and } \\
\text { employee effort } \\
\text { (inverse of sickness } \\
\text { absence) }\end{array}$ & 2 SLS & $\begin{array}{l}\text { information from } \\
\text { the income tax } \\
\text { system) / No }\end{array}$ & $\begin{array}{l}\text { for white-collar workers; very weak, if } \\
\text { any, positive impact for blue-collar } \\
\text { workers } \\
\text { Effort: positive relationship for white- } \\
\text { collar workers, no impact for blue-collar } \\
\text { workers }\end{array}$ \\
\hline $\begin{array}{l}\text { Gomez } \\
(2002)\end{array}$ & US & $\begin{array}{l}\text { Panel data on } 26 \\
\text { professional hockey teams } \\
\text { (773 players), } 1993-98\end{array}$ & $\begin{array}{l}\text { Unconditional: } \\
\text { Gini coefficient }\end{array}$ & $\begin{array}{l}\text { Winning percentage } \\
\text { of teams and } \\
\text { season-ending point } \\
\text { totals }\end{array}$ & $\begin{array}{l}\text { OLS, fixed- } \\
\text { effects and } \\
\text { first } \\
\text { differences }\end{array}$ & No / No & $\begin{array}{l}\text { OLS: positive impact of wage dispersion } \\
\text { on team performance } \\
\text { Fixed-effects: no significant relationship } \\
\text { First differences: negative relationship, } \\
\text { but results depend on the time period }\end{array}$ \\
\hline $\begin{array}{l}\text { Beaumont } \\
\text { and Harris } \\
(2003)\end{array}$ & UK & $\begin{array}{l}\text { Panel data on firms in } 5 \\
\text { industrial sectors, } 1978-95\end{array}$ & $\begin{array}{l}\text { Unconditional: } \\
\text { ratio of non-manual to } \\
\text { manual labour costs per } \\
\text { employee }\end{array}$ & $\begin{array}{l}\text { Gross value added } \\
\text { divided by the } \\
\text { number of workers }\end{array}$ & $\begin{array}{l}\text { System (static } \\
\text { and dynamic) } \\
\text { GMM } \\
\text { estimator }\end{array}$ & $\begin{array}{l}\text { Yes (IV: lagged } \\
\text { values of } \\
\text { repressors) / Yes }\end{array}$ & $\begin{array}{l}\text { Negative (positive) impact of wage } \\
\text { dispersion on firm performance in } 1 \text { (4) } \\
\text { sector(s). }\end{array}$ \\
\hline $\begin{array}{l}\text { Frick et al. } \\
(2003)\end{array}$ & US & $\begin{array}{l}\text { Panel data on professional } \\
\text { baseball }(1985-2001), \\
\text { basketball }(1990-2000), \\
\text { football }(1988,1991, \\
\text { 1995-2005) and hockey } \\
(1988,1993,1995-2000) \\
\text { teams }\end{array}$ & $\begin{array}{l}\text { Unconditional: } \\
\text { Gini coefficient }\end{array}$ & $\begin{array}{l}\text { Win percentage in } \\
\text { the regular season }\end{array}$ & $\begin{array}{l}\text { Fixed- and } \\
\text { random- } \\
\text { effects }\end{array}$ & $\mathrm{No} / \mathrm{No}$ & $\begin{array}{l}\text { Positive (negative) impact of wage } \\
\text { dispersion on the performance of } \\
\text { basketball (baseball) teams } \\
\text { No significant impact for hockey and } \\
\text { football teams. }\end{array}$ \\
\hline $\begin{array}{l}\text { DeBrock et } \\
\text { al. (2004) }\end{array}$ & US & $\begin{array}{l}\text { Panel data on professional } \\
\text { baseball teams, } 1985-98\end{array}$ & $\begin{array}{l}\text { Conditional: } \\
\text { dispersion of the } \\
\text { residuals of wage } \\
\text { regressions and } \\
\text { dispersion of expected } \\
\text { wages using the } \\
\text { Herfindahl index } \\
\text { Unconditional: } \\
\text { Herfindahl index } \\
\text { (without controlling for } \\
\text { workers' differences) }\end{array}$ & $\begin{array}{l}\text { Won-lost } \\
\text { percentage and } \\
\text { attendance at home } \\
\text { games }\end{array}$ & $\begin{array}{l}\text { OLS and } \\
\text { fixed-effects }\end{array}$ & $\mathrm{No} / \mathrm{No}$ & $\begin{array}{l}\text { Negative impact of wage dispersion on } \\
\text { team performance }\end{array}$ \\
\hline $\begin{array}{l}\text { Heyman } \\
(2005)\end{array}$ & Sweden & $\begin{array}{l}\text { Panel data for white-collar } \\
\text { workers and managers in } \\
\text { private sector firms, } 1991\end{array}$ & $\begin{array}{l}\text { Conditional (only for } \\
\text { white-collar workers): } \\
\text { variance of the }\end{array}$ & $\begin{array}{l}\text { Profits divided by } \\
\text { the number of } \\
\text { employees }\end{array}$ & $\begin{array}{l}\text { OLS, 2SLS } \\
\text { and first- } \\
\text { differences }\end{array}$ & $\begin{array}{l}\text { Yes (IV: lagged } \\
\text { values of wage } \\
\text { dispersion) / No }\end{array}$ & $\begin{array}{l}\text { Positive impact for white-collar workers } \\
\text { and managers }\end{array}$ \\
\hline
\end{tabular}




\begin{tabular}{|c|c|c|c|c|c|c|c|}
\hline & & and 1995 & $\begin{array}{l}\text { residuals of wage } \\
\text { regressions } \\
\text { Unconditional: } \\
\text { For white-collar } \\
\text { workers: coefficient of } \\
\text { variation of wages and } \\
\text { 90-10th percentile } \\
\text { wage ratio } \\
\text { For managers: } \\
\text { coefficient of variation } \\
\text { of wages, wage } \\
\text { difference and ratio } \\
\text { between the CEO and } \\
\text { other managers }\end{array}$ & & $\begin{array}{l}\text { using the } \\
\text { random- } \\
\text { effects } \\
\text { estimator }\end{array}$ & & \\
\hline $\begin{array}{l}\text { Koubi and } \\
\text { Roux (2006) }\end{array}$ & France & $\begin{array}{l}\text { Panel data on } 60551 \text { firms, } \\
\text { 1994-2002 }\end{array}$ & $\begin{array}{l}\text { Conditional: } \\
\text { coefficient of variation } \\
\text { of (the exponential of) } \\
\text { the residuals of wage } \\
\text { regressions }\end{array}$ & $\begin{array}{l}\text { Value added and } \\
\text { gross operating } \\
\text { surplus divided by } \\
\text { capital }\end{array}$ & $\begin{array}{l}\text { OLS, long } \\
\text { differences } \\
\text { and GMM }\end{array}$ & $\begin{array}{l}\text { Yes (IV: lagged } \\
\text { values of } \\
\text { explanatory } \\
\text { variables and } \\
\text { evolution of wage } \\
\text { dispersion } \\
\text { indicator) / No }\end{array}$ & $\begin{array}{l}\text { OLS: positive impact of wage dispersion } \\
\text { on value added and gross operating } \\
\text { surplus divided by capital } \\
\text { Long differences : positive (negative) } \\
\text { impact on value added (gross operating } \\
\text { surplus divided by capital) (in most } \\
\text { sectors investigated) } \\
G M M \text { : positive impact of wage } \\
\text { dispersion in most sectors, particularly in } \\
\text { construction }\end{array}$ \\
\hline $\begin{array}{l}\text { Jirjahn and } \\
\text { Kraft (2007) }\end{array}$ & Germany & $\begin{array}{l}\text { Cross-sectional data on } \\
372 \text { manufacturing firms } \\
\text { (blue-collar workers only), } \\
1997\end{array}$ & $\begin{array}{l}\text { Unconditional: } \\
\text { difference between the } \\
\text { highest hourly wage of } \\
\text { a skilled blue-collar } \\
\text { worker and the lowest } \\
\text { hourly wage of an } \\
\text { unskilled blue-collar } \\
\text { worker }\end{array}$ & $\begin{array}{l}\text { Value added } \\
\text { divided by the } \\
\text { number of } \\
\text { employees }\end{array}$ & OLS & No / No & $\begin{array}{l}\text { No uniform (no significant) relationship } \\
\text { when interactions with the industrial } \\
\text { relations regime and the incentive scheme } \\
\text { are (not) taken into account }\end{array}$ \\
\hline $\begin{array}{l}\text { Lallemand et } \\
\text { al. (2007) }\end{array}$ & Belgium & $\begin{array}{l}\text { Cross-sectional data on } \\
397 \text { firms, } 1995\end{array}$ & $\begin{array}{l}\text { Conditional: } \\
\text { standard errors of wage } \\
\text { regressions } \\
\text { Unconditional: }\end{array}$ & $\begin{array}{l}\text { Value added } \\
\text { divided by the } \\
\text { number of workers }\end{array}$ & $\begin{array}{l}\text { OLS and } \\
2 \text { SLS }\end{array}$ & $\begin{array}{l}\text { Yes (IV: intra-firm } \\
\text { standard deviation } \\
\text { of income taxes on } \\
\text { gross earnings } \\
\text { excluding }\end{array}$ & $\begin{array}{l}\text { Positive relationship, stronger for blue- } \\
\text { collar workers and within firms with a } \\
\text { high degree of monitoring }\end{array}$ \\
\hline
\end{tabular}




\begin{tabular}{|c|c|c|c|c|c|c|c|}
\hline & & & $\begin{array}{l}\text { standard deviation, } \\
\text { coefficient of variation } \\
\text { and max-min ratio of } \\
\text { wages }\end{array}$ & & & bonuses) / No & \\
\hline $\begin{array}{l}\text { Braakmann } \\
(2008)\end{array}$ & $\begin{array}{l}\text { (West) } \\
\text { Germany }\end{array}$ & $\begin{array}{l}\text { Panel data on } 11,000 \\
\text { firms, 1995-2005 }\end{array}$ & $\begin{array}{l}\text { Conditional: } \\
\text { standard deviation of } \\
\text { the residuals of wage } \\
\text { regressions } \\
\text { Unconditional: } \\
\text { coefficient of variation } \\
\text { of wages (in the firm as } \\
\text { a whole and within } \\
\text { subgroups) }\end{array}$ & $\begin{array}{l}\text { Sales divided by the } \\
\text { number of workers }\end{array}$ & $\begin{array}{l}\text { Fixed-effects } \\
\text { and dynamic } \\
\text { difference } \\
\text { GMM } \\
\text { estimator }\end{array}$ & Yes / Yes & $\begin{array}{l}\text { Fixed-effects: negative or U-shaped } \\
\text { relationship } \\
G M M \text { : insignificant relationship }\end{array}$ \\
\hline $\begin{array}{l}\text { Grund and } \\
\text { Westergaard- } \\
\text { Nielsen } \\
(2008)\end{array}$ & Denmark & $\begin{array}{l}\text { Panel data on 5,736 firms, } \\
\text { 1992-97 }\end{array}$ & $\begin{array}{l}\text { Dispersion of wage } \\
\text { levels: Unconditional, } \\
\text { i.e. coefficient of } \\
\text { variation of wages } \\
\text { Dispersion of wage } \\
\text { increases: } \\
\text { Unconditional, i.e. } \\
\text { coefficient of variation } \\
\text { of individual wage } \\
\text { increases }\end{array}$ & $\begin{array}{l}\text { Value added } \\
\text { divided by the } \\
\text { number of } \\
\text { employees }\end{array}$ & $\begin{array}{l}\text { OLS and } \\
\text { fixed-effects }\end{array}$ & No / Yes & $\begin{array}{l}\text { Dispersion of wage levels: hump-shaped } \\
\text { relationship with OLS, no significant } \\
\text { relationship with fixed-effects } \\
\text { Dispersion of wage increases: U-shaped } \\
\text { relationship } \\
\text { Results are mainly driven by white-collar } \\
\text { rather than blue-collar workers }\end{array}$ \\
\hline $\begin{array}{l}\text { Martins } \\
(2008)\end{array}$ & Portugal & $\begin{array}{l}\text { Panel data on } 4,735 \text { firms, } \\
1991-2000\end{array}$ & $\begin{array}{l}\text { Conditional: } \\
\text { standard deviation and } \\
\text { difference between the } \\
\text { 90th and 10th } \\
\text { percentiles of the } \\
\text { residuals of wage } \\
\text { equations including } \\
\text { both worker and firm } \\
\text { fixed-effects }\end{array}$ & $\begin{array}{l}\text { Sales divided by the } \\
\text { number of workers }\end{array}$ & $\begin{array}{l}\text { OLS and } \\
\text { fixed-effects }\end{array}$ & $\mathrm{No} / \mathrm{No}$ & $\begin{array}{l}\text { OLS: positive relationship } \\
\text { Fixed-effects: negative relationship }\end{array}$ \\
\hline $\begin{array}{l}\text { Hunnes } \\
(2009)\end{array}$ & Norway & $\begin{array}{l}\text { Panel data covering white- } \\
\text { collar workers (only full- } \\
\text { time) in } 1,723 \text { firms, } \\
1986-97\end{array}$ & $\begin{array}{l}\text { Dispersion in the fixed } \\
\text { component of wages: } \\
\text { Conditional, i.e } \\
\text { standard deviation of }\end{array}$ & $\begin{array}{l}\text { Gross production } \\
\text { value and profits } \\
\text { divided by the } \\
\text { number of }\end{array}$ & $\begin{array}{l}\text { OLS, } 2 \text { SLS, } \\
\text { and fixed- } \\
\text { effects }\end{array}$ & $\begin{array}{l}\text { Yes (the bonus } \\
\text { dummy is } \\
\text { instrumented by } \\
\text { the union density }\end{array}$ & $\begin{array}{l}\text { OLS : positive relationship between the } \\
\text { dispersion in the fixed component of } \\
\text { wages and firm performance } \\
\text { Fixed effects: no significant relationship }\end{array}$ \\
\hline
\end{tabular}




\begin{tabular}{|c|c|c|c|c|c|c|c|}
\hline & & & $\begin{array}{l}\text { the residuals of fixed- } \\
\text { effects wage equations } \\
\text { where the parameters } \\
\text { do not vary within or } \\
\text { between firms over } \\
\text { time (controlling or not } \\
\text { for the hierarchical } \\
\text { levels) } \\
\text { Unconditional, i.e. } \\
\text { coefficient of variation } \\
\text { of wages and Theil } \\
\text { index (decomposed in a } \\
\text { within- and a between- } \\
\text { hierarchical level) } \\
\text { Dispersion in the } \\
\text { variable component of } \\
\text { wages: Unconditional, } \\
\text { i.e. standard deviation } \\
\text { of bonuses and dummy } \\
\text { variable for bonuses }\end{array}$ & employees & & $\begin{array}{l}\text { and its lagged } \\
\text { values) / No }\end{array}$ & $\begin{array}{l}\text { between the dispersion in the fixed } \\
\text { component of wages and firm } \\
\text { performance } \\
\text { No robust relationship between bonus } \\
\text { payments and firm performance }\end{array}$ \\
\hline $\begin{array}{l}\text { Mahy et al. } \\
(2010)\end{array}$ & Belgium & $\begin{array}{l}\text { Cross-sectional data on } \\
649 \text { firms, } 2003\end{array}$ & $\begin{array}{l}\text { Conditional: standard } \\
\text { deviation of the } \\
\text { residuals of wage } \\
\text { regressions } \\
\text { Unconditional: } \\
\text { standard deviation and } \\
\text { coefficient of variation } \\
\text { of wages }\end{array}$ & $\begin{array}{l}\text { Value added } \\
\text { divided by the } \\
\text { number of workers }\end{array}$ & OLS & $\begin{array}{l}\text { Yes (one year-lead } \\
\text { firm productivity } \\
\text { regressed on } \\
\text { current wage } \\
\text { dispersion) / No }\end{array}$ & $\begin{array}{l}\text { Hump-shaped relationship, stronger for } \\
\text { highly skilled workers and in more stable } \\
\text { environments }\end{array}$ \\
\hline
\end{tabular}


Appendix 2. Descriptive statistics: all firms vs. firms observed for at least two consecutive years

\begin{tabular}{|c|c|c|}
\hline Variables: & All firms & $\begin{array}{c}\text { Firms observed } \\
\text { for at least two } \\
\text { consecutive years }\end{array}$ \\
\hline Hourly value added $\left(€^{I}\right)$ & $\begin{array}{c}55.17 \\
(500.8)\end{array}$ & $\begin{array}{c}61.46 \\
(490.47)\end{array}$ \\
\hline Gross hourly wage $\left(€^{l}\right)$ & $\begin{array}{l}15.98 \\
(5.76)\end{array}$ & $\begin{array}{c}16.8 \\
(5.53)\end{array}$ \\
\hline Gross monthly wage $\left(€^{l}\right)$ & $\begin{array}{l}2476.93 \\
(929.27)\end{array}$ & $\begin{array}{l}2637.8 \\
(918.65)\end{array}$ \\
\hline \multicolumn{3}{|l|}{ Intra-firm wage dispersion $\left(€^{l}\right)$ : } \\
\hline Conditional wage dispersion ${ }^{2}$ & $\begin{array}{c}0.15 \\
(0.09)\end{array}$ & $\begin{array}{c}0.16 \\
(0.09)\end{array}$ \\
\hline Unconditional standard deviation of wages ${ }^{3}$ & $\begin{array}{l}5.03 \\
(7.49)\end{array}$ & $\begin{array}{c}5.63 \\
(8.58)\end{array}$ \\
\hline Size of the firm (number of workers) & $\begin{array}{c}125.58 \\
(355.17)\end{array}$ & $\begin{array}{c}220.3 \\
(504.54)\end{array}$ \\
\hline \multicolumn{3}{|l|}{ Age $(\%)$} \\
\hline Less than 25 years & $\begin{array}{c}9.12 \\
(10.31)\end{array}$ & $\begin{array}{c}8.09 \\
(8.53)\end{array}$ \\
\hline Between 25 and 49 years & $\begin{array}{c}75.22 \\
(13.71)\end{array}$ & $\begin{array}{c}75.86 \\
(12.87)\end{array}$ \\
\hline 50 years and more & $\begin{array}{c}15.66 \\
(12.89)\end{array}$ & $\begin{array}{c}16.05 \\
(12.45)\end{array}$ \\
\hline Women $(\%)$ & $\begin{array}{l}26.15 \\
(24.29)\end{array}$ & $\begin{array}{l}24.78 \\
(22.87)\end{array}$ \\
\hline \multicolumn{3}{|l|}{ Education $(\%)$ : } \\
\hline No degree, primary/lower secondary & $\begin{array}{c}37.96 \\
(34.66)\end{array}$ & $\begin{array}{c}36.65 \\
(32.57)\end{array}$ \\
\hline General upper secondary, technical/artistic/prof. upper secondary & $\begin{array}{c}39.68 \\
(30.52)\end{array}$ & $\begin{array}{c}39.34 \\
(28.43)\end{array}$ \\
\hline Higher non university, university and post graduate & $\begin{array}{c}22.36 \\
(26.55)\end{array}$ & $\begin{array}{c}24.00 \\
(25.54)\end{array}$ \\
\hline Blue-collar workers ${ }^{4}(\%)$ & $\begin{array}{c}57.14 \\
(35.13)\end{array}$ & $\begin{array}{c}58.35 \\
(33.18)\end{array}$ \\
\hline Firm-level collective agreement $(\%)$ & $\begin{array}{c}16.92 \\
(37.49)\end{array}$ & $\begin{array}{c}27.16 \\
(44.48)\end{array}$ \\
\hline \multicolumn{3}{|l|}{ Sector $(\%)$ : } \\
\hline Mining and quarrying $(\mathrm{C})$ & 0.37 & 0.62 \\
\hline Manufacturing (D) & 45.57 & 57.42 \\
\hline Electricity, gas and water supply (E) & 0.07 & 0.06 \\
\hline Construction $(\mathrm{F})$ & 13.19 & 11.84 \\
\hline $\begin{array}{l}\text { Wholesale and retail trade, repair of motor vehicles, motorcycles } \\
\text { and personal and household goods }(G)\end{array}$ & 17.01 & 10.87 \\
\hline Hotels and restaurants $(\mathrm{H})$ & 2.77 & 1.37 \\
\hline Transport, storage and communication (I) & 7.9 & 5.61 \\
\hline Financial intermediation $(\mathrm{J})$ & 1.04 & 1.38 \\
\hline Real estate, renting and business activities (K) & 12.1 & 10.83 \\
\hline Number of observations & 20,613 & 6,789 \\
\hline Number of firms & 9,254 & 2,494 \\
\hline
\end{tabular}

Notes: Standard deviations are shown in brackets.

${ }^{1}$ At 2006 constant prices. ${ }^{2}$ Hourly residual wage dispersion after controlling for human capital variables and workers' characteristics in the wage equation following the Winter-Ebmer and Zweimüller (1999) methodology (i.e. standard deviations of residuals of wage regressions run for each firm and each year separately). ${ }^{3}$ Standard deviation of gross hourly wages within each firm. ${ }^{4}$ The distinction between blue- and white-collar workers is based on the International Standard Classification of Occupations (ISCO-88). Workers belonging to groups 1 to 
5 are considered to be white-collar workers (1: Legislators, senior officials and managers; 2: Professionals; 3 : Technicians and associate professionals; 4: Clerks; 5: Service workers and shop and market sales workers) and those from groups 7 to 9 are considered to be blue-collar workers (7: Craft and related trades workers; 8: Plant and machine operators and assemblers; 9: Elementary occupations). 